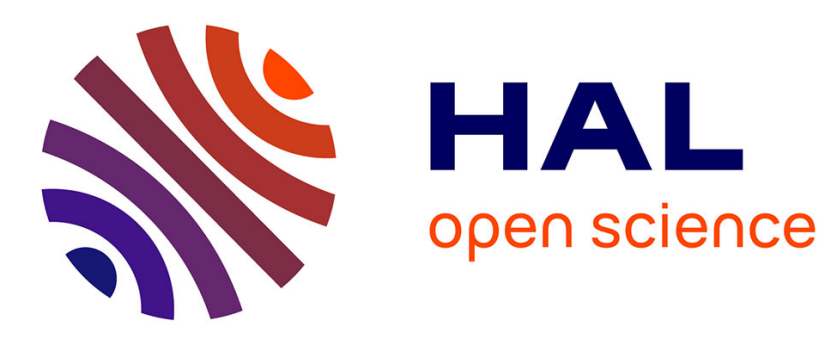

\title{
Should Employment Authorities Worry About Mergers and Acquisitions?
}

David Margolis

\section{To cite this version:}

David Margolis. Should Employment Authorities Worry About Mergers and Acquisitions?. Portuguese Economic Journal, 2006, 5 (2), pp.167-194. 10.1007/s10258-006-0007-4 . halshs-00202292

\section{HAL Id: halshs-00202292 \\ https://shs.hal.science/halshs-00202292}

Submitted on 8 Jan 2008

HAL is a multi-disciplinary open access archive for the deposit and dissemination of scientific research documents, whether they are published or not. The documents may come from teaching and research institutions in France or abroad, or from public or private research centers.
L'archive ouverte pluridisciplinaire HAL, est destinée au dépôt et à la diffusion de documents scientifiques de niveau recherche, publiés ou non, émanant des établissements d'enseignement et de recherche français ou étrangers, des laboratoires publics ou privés. 


\title{
Should Employment Authorities Worry About Mergers and Acquisitions?
}

\author{
David N. MARGOLIS \\ Centre d'Economie de la Sorbonne, Université Paris 1 Panthéon-Sorbonne, CNRS; \\ CREST-INSEE; IZA
}

Running head: "Employment, Mergers and Acquisitions"

\author{
Mailing address: \\ David Margolis \\ Centre d'économie de la Sorbonne \\ Maison des Sciences Economiques \\ Université Paris 1 Panthéon-Sorbonne \\ 106-112 boulevard de l'Hôpital \\ 75647 Paris Cedex 13 \\ France \\ E-mail : David.Margolis@univ-paris1.fr.
}

Acknowldegments: This paper is based on two earlier works, "Compensation Policy, Human Resource Management Practices and Takeovers" and "Mergers, Acquisitions and Employment". The author would like to thank two anonymous referees and participants in numerous seminars and conferences for helpful comments. 


\begin{abstract}
This paper considers the role mergers and acquisitions on employment. First, it considers the importance of different aspects of compensation policy and human resource management practices for distinguishing acquired and acquiring firms. Second, it examines which individuals from which firms remain with the newly created entity after the takeover. Using a unique employer-employee linked data set for France, we find that very few observable workforce or compensation characteristics distinguish acquired from acquiring firms ex-ante. Nevertheless, the human resources department seems to be quite active in the post-takeover period, with employees of the acquired firm having a lower probability of continued employment with the new entity in the short term after takeover than those of the acquiring firm and with the differences between the two types of firms disappearing after 3 years. The workers with characteristics that tend to be associated with the fastest subsequent job finding in the displaced worker literature are also those who tend to be overrepresented among the individuals who separate from their employer posttakeover. Finally, as both acquired and acquiring firms differ from firms not involved in takeover activity in a similar manner, employment authorities may be able to anticipate the regions in which takeovers are more likely to occur by looking at the financial accounts of firms with particular characteristics that have local establishments.
\end{abstract}

Key Words: Employment, Takeovers, Linked Employer-Employee Data JEL Codes/ Codes JEL : G34, J21, J23, J31, J63, L29, M51 


\section{Introduction}

When the popular press talks about mergers and acquisitions, the discussion is most frequently oriented towards the employment effects of the transaction. Terms like "downsizing" and "rationalization" are typically euphemisms for mass layoffs, while talk of "synergies" is taken as code for impending plant closures. As such, one might expect labor authorities to be particularly concerned about the employment consequences of mergers and acquisitions involving firms with establishments in their jurisdictions.

But should they be concerned? In other words, do the entities involved in mergers and acquisitions lay off more workers than similar firms under "normal" circumstances? Do the workers that get laid off find it harder to get back to work after the layoff than workers let go by other firms? And more proactively, is there any dimension that employment authorities might be able to use to plan ahead, in order to anticipate which plants and workers are more likely to be involved in a merger or acquisition?

This paper uses a unique linked employer-employee data set (LEED) from France to attempt to answer all of these questions. Drawing on new results on mergers and acquisitions in France in the 1990s and results in the existing literature on displaced workers, we find that, on the whole, there is little cause for alarm. Although acquired firms tend to lay workers off more in the short term than their acquirers, the differences in the continued employment probability for a worker employed in either sort of firm in the year prior to the transaction is essentially the same 3 years after the transaction takes place. Furthermore, this continued employment probability is much higher than the comparable probability for workers employed in firms with no 
takeover activity. In addition, the workers that are laid off disproportionately tend to posses characteristics that are associated with faster job finding after a displacement, meaning that they may be easier to place than the average laid off worker. Finally, there seem to be few workforce-related characteristics of firms that might be useful for identifying potential participants in future merger and acquisition activity, suggesting that the scope for planning is limited essentially to analysis of the corporate accounts of firms that employ workers in the relevant jurisdiction.

The rest of this paper proceeds as follows. After briefly discussing the theoretical framework underlying the analysis in section 2, section 3 lays out the statistical models that we exploit to investigate the determinants of takeovers and of continued employment, while section 4 briefly describes construction of the analysis samples and provides some motivating descriptive statistics. ${ }^{1}$ Section 5 provides a parametric analysis of the determinants of mergers and acquisitions while section 6 considers the structure of post-takeover separations. Section 7 discusses how employment authorities might want to interpret these results and concludes.

\section{Theoretical Framework}

This section briefly discusses the reasons for takeovers discussed in the economics literature. From a theoretical point of view, one can identify six different frameworks that have been used to address the motivations behind merger and acquisition activity. One major advantage of our data is that they allow us to measure a large number of management decision variables (as we have access to balance sheet and income statement information as well as data on each firm's work force). We can

${ }^{1}$ Details on the four data sets that are merged to create the analysis data set are provided in Appendix A. 
thus control for many alternative explanations for takeovers while focusing in detail on the firm's compensation policy and human resource management practices when trying to identify which firms are most likely to be involved in takeover activity.

\subsection{Controlling the Actions of Incumbent Management (Jensen \&}

\section{Meckling, 1976)}

The most common approach in the corporate finance literature to analyzing mergers and acquisitions (Manne, 1965; Jensen and Meckling, 1976; Jensen, 1984, 1986, 1988) treats takeovers as a means by which the market exerts control over managerial decisions. If a manager's decisions are considered to be suboptimal by the market, in the sense that they do not maximize shareholder value, then an outsider can acquire the firm, fire the manager, replace him or her with a better manager, and realize efficiency gains. Since the stock market value of the firm is based upon the realized (and inefficient) decisions of the incumbent management, there is an opportunity for an outsider to profit from a takeover.

An implication of this theory is that there are some aspects of a firm that are observable by outsiders and which make it more likely to be the target of a takeover attempt than the average firm. ${ }^{2}$ Another implication is that this quantity should change between the period preceding the takeover and the period following the takeover. Although the theory is sufficiently general to accommodate inefficient decisions in investment strategy, capital structure choices (Modigliani-Miller notwithstanding) and

\footnotetext{
${ }^{2}$ In the United States and Canada, union contracts can be a major, and visible, target of potential cost reductions. In France, however, sector-wide collective agreements are pervasive and the Ministry of Labor has the authority to apply them to all firms in the sector, thus removing the possibility of renegotiation of contracts for the acquirer. Enterprise agreements are also prevalent and they can cover compensation issues (although the law only requires negotiation over safety and working conditions). However, since these are not observable to outsiders they can not serve as a motivation ex ante for takeover or merger activity in this framework.
} 
research and development spending, the popular press (at the least) suggests that a commonly considered aspect of the firm may be the compensation structure or the human resource management policies adopted by its managers.

Among the (relatively few) papers that analyze the employment and compensation aspects of firms involved in takeovers (e.g. Brown and Medoff,1988; Gokhale, Groshen and Neumark, 1995), Bertrand and Mullainathan (2003) explicitly consider the link between the compensation policy adopted by U.S. firms and their risk of being taken over. By exploiting differences in takeover legislation, they show that firms that are relatively protected from the risk of takeover tend to increase wages relative to more exposed firms. This is consistent with the Jensen and Meckling hypothesis, insofar as the higher wages paid to the workers are not justified through extra effort exerted by workers (an efficiency wage-type effect) or by changes in human resource management practices that involve retaining more productive workers.

\subsection{Costly Capital and the Lack of Investment Opportunities}

Another strand of the literature treats takeovers as a means by which older firms can grow. As a firm matures, it optimally exploits its highest marginal returns investment opportunities for organic growth first and the lower marginal return investment opportunities later in its life cycle. The exploitation of these investment opportunities is financed either through the issuance of debt or equity. The cost of this additional capital depends on the existing capital structure of the firm, with less indebted firms having more access to less expensive capital due to their lower default risk. A lower cost of capital allows firms to pursue investment opportunities with relatively lower expected marginal returns. Conversely, a heavily indebted firm may 
have highly profitable opportunities for organic growth available but it may find itself unable to finance these investments due to the high cost of obtaining the necessary capital.

In such a situation, a firm with a healthy capital structure may acquire (potentially) fast-growing, but highly indebted, firms. The market price of these target firms will not incorporate the returns to the unexploitable investment opportunities, but an injection of outside capital from a potential acquirer with a better capital structure will allow the new entity to realize the high-return investments. If the acquiring firm is large enough, the addition of the acquired firm's debt to its balance sheet will not overly adversely affect its cost of capital, and the acquisition becomes profitable.

\subsection{Attaining a Critical Mass (Bradley, Desai and Kim, 1983)}

A very simple reason for acquisitions may be the existence of increasing returns to scale in production. If a firm employs a production technology which is particularly efficient at high volumes of output but is unable to generate enough demand on its own, it may attempt to acquire additional distribution outlets or access to additional markets in order to exploit the cost advantages of large scale production inherent in its technology. As a result, the new entity can produce the same output at a lower cost than either of the pre-existing firms and the realized gains can be used to offset the costs of the acquisition. 


\subsection{Increasing Market Share (Eckbo, 1983; Borenstein, 1990)}

When a firm has a substantial degree of market power, even without going as far as a monopoly, it can often exercise a certain degree of control over market prices and output levels, thereby improving profitability. In order to attain sufficient market share, firms may attempt to buy competitors. Of course, such strategies are frowned upon by competition authorities and are thus rarely presented to the media under this angle.

\subsection{Enforcement of a Threat under Tacit Collusion (Compte, Jenny} and Rey, 2002)

Several game-theoretic models of acquisitions have insisted upon the importance of acquisition as a means of enforcing threats within a cartel. Since acquisitions to gain market power and affect prices directly are often subject to antitrust scrutiny, firms may opt for an oligopolistic arrangement with cartel pricing to maximize the profits of the cartel members. However, since the cartel price is above marginal cost in these models, there is an incentive for a cartel member to deviate from the agreement and undercut the price of other members. In this case, other members of the cartel may use the threat of takeover to enforce the arrangements and they may occasionally need to act on this threat in order to maintain its credibility.

\subsection{Insuring Against Market-Specific Risks (Matsusaka, 1993)}

If a firm is in a sector that is subject to important demand or input price fluctuations, it may seek to insure its share price against these fluctuations by 
diversifying into other, more stable, sectors or sectors with counterbalancing risks. This conglomeration approach, popular in the 1980s, has gradually been abandoned by the literature as authors have decided that individuals investors should optimize their portfolios by selecting a set of firms whose idiosyncratic or sectoral risks offset each other while the firms themselves should focus on their "core competences".

\section{Modeling Takeovers and Post-Takeover Employment}

This paper bases its analysis primarily on the Jensen and Meckling (1976) framework, which has several implications. First, since an acquiring firm decides on its target based on what it perceives as opportunities to improve efficiency or profitability, only variables that are observable to an outside firm should affect the determination of which firms are acquired and which are not. In particular, in the year preceding the transaction, acquired and acquiring firms should differ primarily along dimensions that are reflected in a firm's accounts (which are published for publicly traded firms and some private firms) and compensation policy (some aspects of which are reflected in the income statement part of a firm's accounts). Most dimensions of a firm's human resource management policy should not therefore be significant determinants of the difference between acquired and acquiring firms.

However, in the post transaction period, the acquiring firm has access to information that was not previously available when the takeover decision was made. Accordingly, when it proceeds with modifications that it judges necessarily to recover the rents that motivated the transaction in the first place, it may also restructure the composition or size of the workforce even though these variables did not enter into the takeover decision. 
In order to empirically asses the validity of these implications, one needs to both estimate the determinants of takeovers and consider the evolution of employment in the post-takeover period. Some individuals with "inappropriate" characteristics should find continued employment significantly less likely post-transaction than individuals whose characteristics are better suited to the efficient production. In addition, if screening individuals is costly even for the acquiring firm, one may see evolution post-transaction in the composition of the acquiring firm's workforce as individuals who are already "in house" (due to the acquisition) displace incumbents from the acquiring firm who are less well suited to their jobs than the newcomers.

\subsection{Workforce Composition and Compensation Policy}

As noted above, the theoretical framework requires us to include measures of compensation policy (which should be related to takeovers and post-takeover employment) and workforce composition (which should be related to post-takeover employment but not takeover probabilities). Although some components of workforce composition are observable, unobserved worker quality may be a significant determinant of post-takeover employment while distinguishing compensation policy from workforce composition, especially in the presence of unobserved worker heterogeneity and heterogeneous compensation policies, requires specific statistical techniques.

We apply here the persons-first, firms-first projection-based estimation technique described in Abowd, Kramarz and Margolis (1999) in order to decompose total compensation into its various components. This technique is based upon estimation of the following statistical model. 


$$
y_{i t}=\mu_{y}+\left(x_{i t}-\mu_{x}\right) \beta+\theta_{i}+\psi_{J(i, t)}+\varepsilon_{i t}
$$

In this model, $y_{i t}$ is the log full-year equivalent real compensation cost (gross earnings plus employer payroll taxes) for individual $i$ at date $t . x_{i t}$ is the set of individual-specific, time varying characteristics for individual $i$ at date $t$ (experience and region of residence) while $\theta_{i}$ summarizes the return to time-invariant individualspecific characteristics. $\psi_{J(i, t)}$ refers to the firm-specific component of compensation for the firm $j=J(i, t)$ that employs individual $i$ at date $t . \mu_{y}$ is the overall mean of $y_{i t}, \mu_{x}$ is the overall mean of $x_{i t}$ and $\varepsilon_{i t}$ is a statistical residual. We decompose the time-invariant individual-specific component into two orthogonal terms as $\theta_{i}=u_{i} \eta+\alpha_{i}$, where $u_{i}$ represents observable time invariant characteristics (sex and education) and $\alpha_{i}$ represents unobserved individual-specific time-invariant heterogeneity, which we loosely refer to as "worker quality". We decompose the firmspecific component of compensation $\psi_{J(i, t)}$ as $\psi_{J(i, t)}=\phi_{J(i, t)}+\gamma_{J(i, t)} s_{i t}$, where $s_{i t}$ represents job seniority for individual $i$ at date $t, \phi_{J(i, t)}$ is the initial wage in the firm that employs individual $i$ at date $t$ and $\gamma_{J(i, t)}$ represents the returns to job seniority in this firm.

\subsection{Empirical Evaluation of the Probability of Takeover}

Since the first empirically testable implication of the theory concerns which firm characteristics should affect the probability of takeover and which ones should not, one must begin by modeling the probability of takeover. To do this, we estimate a series of simple logit models on our estimation sample (see section 4 below). These models capture the probability of a firm being acquired relative to its being an 
acquirer, the probability of being acquired relative to having no takeover activity and the probability of being a firm that acquires another firm relative to having no takeover activity. ${ }^{3}$ The first model allows us to analyze what distinguishes acquired firms from their acquirers while the latter models allow us to characterize acquired and acquiring firms as a whole (relative to "control" firms). These estimations can be useful for identifying firms at risk of being involved in a takeover and for distinguishing which side of the transaction a given firm might find itself.

All of our models include covariates that describe compensation policy (the $\phi_{J(i, t)}, \gamma_{J(i, t)}, \gamma_{J(i, t)} s_{i t}$ and $\varepsilon_{i t}$ terms in section 3.1), workforce composition (firmyear averages of the observable variables in $x_{i t}, u_{i}, s_{i t}, \alpha_{i}, x_{i t} \beta$ and $\theta_{i}$ and firm accounts (property, plant \& equipment after depreciation and amortization (capital stock), percentage change in capital stock from $t-1$ to $t$, ratio of debt to total assets, return on assets, value added per worker, total employment, capital stock per worker, sales per worker and sales per unit of capital). ${ }^{4}$ We also include a set of indicator variables to control for the year of the observation and for the broad (1-digit) sector.

\footnotetext{
${ }^{3}$ Instead of estimating three simple logits, one could estimate a single multinomial logit model. The results would be analytically identical (given the independence of irrelevant alternatives hypothesis implicit in the multinomial logit model), but the interpretation is easier in the case of several simple logit models. In the simple logit case, the differences between any two categories are visible in te estimated coefficients. On the other hand, one must difference the coefficients between the two nonreference group categories (and recompute standard errors) in a multinomial logit context in order to interpret the differences between the two categories.

${ }^{4}$ The $\gamma_{J(i, t)} s_{i t}, x_{i t} \beta$ and $\theta_{i}$ represent terms in the model that interact observable characteristics with market values. These terms are included since they may have provide explanatory power in the discrete models for the probability of takeover as they impose a relative weighting scheme drawn from the labor market, where additional variation in the components of these terms reflects differences in the labor markets weights on the characteristics for the determination of compensation and the capital market's determination of weights for the purposes of measuring long-term rent maximization for shareholders. It should be noted, however, that the identification of these terms derives essentially from the two-step nature of the estimators and the nonlinearity of the functional form chosen for the takeover models.
} 


\subsection{Empirical Evaluation of the Probability of Continued Employment}

After modeling the determinants of takeovers, we then consider the determinants of the probability of separating from one's employer. Conditional on being employed in the year preceding the transaction (or in a given year for control firms), we begin by calculating the probability of remaining employed with the new entity (or the same firm for individuals in control firms) 1 to 5 years after the transaction. ${ }^{5}$ The probability of continued employment in acquired and acquiring firms, relative to the probability of continued employment in control firms, is shown on average for employees of both acquired and acquiring firms, and this relative probability is then decomposed by sector (manufacturing versus services) and by the relation between the acquiring and acquired firm (in the same or different 4-digit industry). This analysis allows us to see where most of the separations occur posttransaction, either in the acquired or the acquiring firm.

We then pursue the analysis of continued employment with a set of logit models in which we model the probability of continued employment 1-5 years after the transaction for those individuals employed in single-takeover firms in the year before the transaction (and in any year for control firms). Although this approach does not account for censoring in the data in the same manner as a standard (parametric or semi-parametric) duration model, it has the advantage of allowing the effects of covariates to vary, and even change sign, over the duration of the episode. These

\footnotetext{
${ }^{5}$ Note that not all individuals will have data available to participate in the estimation of all of these continued employment probabilities. An individual whose firm was acquired in 1996, for example, will only have 2 years of post acquisition data whereas an individual whose employer was bought in 1993 will have all 5 years available. These continued employment probabilities are estimated as (stratified) Kaplan-Meier survivor functions.
} 
models employ the same set of covariates as the models used to determine the probability of takeover. ${ }^{6}$

It should be noted that we are interested in the probability of continued employment with the new entity created as a result of the merger or acquisition. We are not considering the probability of employment anywhere in the period following the transaction, only with the participants. The question addressed here is narrower since any non employment in the period following the transaction puts an end to the continued employment spell. On the other hand, it is better defined since one is not required to choose an arbitrary lapse of time after which one would be interested in evaluating the probability of employment. This latter strategy is more closely related to the displaced worker literature; see Margolis (2002) for details on the French case.

\section{The Data}

This paper exploits 4 different French data sets, all provided by France's National Institute for Statistics and Economic Studies (INSEE). The different sources of enterprise data have the advantage of using a common identifier for the enterprises involved, and the linked employer-employee data uses the same firm identifier as well as an individual identifier which is also common to the remaining individual data set. As a result, all four data sets can be merged, providing an extensive amount of information all in one place. Appendix A provides details on each of the data sets separately, while this section discusses sample statistics on the merged sample.

\footnotetext{
${ }^{6}$ One could allow for coefficients that change sign in the context of a duration model, but doing so requires the (arbitrary) designation of periods during which a coefficient should remain constant and dates at which it can change. Furthermore, if one has no a priori information about which variables signs might change then one should allow for time-varying coefficients on all of the variables in the duration model, and this implies adding a large number of (potentially useless) interaction terms to the model. The repeated logit approach we adopt here, although it does not appropriately handle right censoring, imposes much less structure on the duration process and avoids the extraneous variables problem by only having a single set of coefficients present in each logit regression.
} 
It is important to note at this stage that the classification of firms into acquired, acquiring and non takeover firms is performed by INSEE, which assigns a transaction type code to all asset transfers over a certain size. Several different values of this code explicitly state that the firm was acquired, acquired another firm or merged with another firm. Since the file provides the firm identifier(s) of the enterprise(s) described as "acquired" and the identifier(s) of the enterprise(s) described as “acquiring”, we make no additional judgments on the nature of the transaction nor do we have any particular difficulty in identifying which firm is on which side of the transaction, provided the data set compiled by the National Statistics Institute is accurate (which we assume it to be).

It should be noted that the ex-post sampling scheme in our merged data is determined by the combination of the sampling schemes of the component data sets. As such, it depends both on the individual selection criterion of the main LEED set (a random 1/25 sample of individuals employed any job outside the central government) and the firm selection criterion of the firm accounts and takeover data. Given all of these criteria, our data will tend to under sample small firms in general, and the takeover data sampling scheme implies that we will miss the smallest asset transfers, although the 8M French Franc threshold does not seem particularly high. The firm account data sampling scheme implies that there may be some smaller asset transfers that escape our analyses as well when one of the firms involved is not part of the early "sample" that is used by INSEE to calculate its advanced economic indicators. ${ }^{7}$

Table 1 provides some basic descriptive statistics for the full, merged sample and the various subsamples considered here. Of the almost 4.6 million observations

\footnotetext{
${ }^{7}$ Note that the inability to match one partner in a takeover to the firm account data does not mean that all data from all other (sufficiently large or "sample") firms is eliminated.
} 
initially available ${ }^{8}$, our selection criterion of eliminating firms with multiple takeover events (357392 observations) or a level of assets that never crossed the threshold for eligibility in the takeover data during the analysis period (262378 observations) only reduces the overall sample size by $13 \%$. The analysis sample very closely resembles the full sample, although the employment-weighted average firm size is slightly higher and the rate of investment in capital is lower, as is value added per worker.

As has been noted elsewhere (Margolis and Simonnet, 2002), the importance of the sub-high school technical or professional degrees in France is also clear in our data, with observations corresponding to such individuals making up roughly 20 percent of the sample. ${ }^{9}$ Our sample is over 60 percent male (with men being slightly overrepresented in acquired firms), and average job seniority varies from 4.7 years in acquired firms to 7.8 years in acquiring firms, although there is significant variation in the data.

Our data suggest several important first-order differences between acquired and acquiring firms. In particular, individuals employed by acquired firms are, on average, "better" than those employed elsewhere, as measured by returns to time invariant characteristics (both observable and unobservable). On the other hand, their time-varying characteristics are much less well rewarded in firms that are taken over than elsewhere. In terms of compensation policy, taken over firms tend to pay slightly more on (employment-weighted) average than other firms, although they reward seniority less well. That said, there remains significant variability in firm

\footnotetext{
${ }^{8}$ It is worth recalling that an observation is a unique individual-firm-year combination containing information from all 4 data sources.

${ }^{9}$ As noted in appendix A.3, the education variable is only available in the data for $1 / 10$ of the sampled individuals and is imputed for the remaining $9 / 10$. Thus although our technique allows us to construct unbiased estimators of the probability of obtaining each given diploma (and it is these probabilities that are used for the imputed individuals), our results concerning the role of education should be interpreted with care.
} 
compensation policy with respect to all three components (Margolis, 1996) and in the firm accounts variables as well.

\section{Which Firms Are Acquired, Which Are Acquirers?}

In this section we explore the determinants of the probability of being involved in takeover activity, either as an acquired or acquiring firm. To do this we undertake a series of simple logit regressions, which provide a cleaner view of the role of the various possible determinants of takeover and separation activity.

The economic models of Section 2 imply that unsuitable compensation policies and human resource management practices, when observable to outsiders, may make a firm the target of a takeover, while the acquiring firm may already be engaging in the sorts of compensation policies and human resource management practices that it intends to impose upon the firms it acquires. Table 2 provides the results of a set of logit regressions that address this issue in more detail. ${ }^{10}$

Table 2 explicitly considers the probability of a firm's being taken over or taking over another firm. The first column models the determinants that make a firm engaged in takeover activity more likely to be taken over than taking over another firm. In other words, this column serves to highlight the characteristics that differ between acquired and acquiring firms, with a positive coefficient implying that the corresponding characteristic is overrepresented in the population of acquired firms (relative to its distribution in acquiring firms). The second column performs the same sort of analysis but uses firms with no takeover activity as a reference when

\footnotetext{
${ }^{10}$ In order to reduce the risk of endogeneity, these logit regressions use only pre-transaction observations for firms involved in takeover activity and all observations for non-takeover firms.
} 
considering the characteristics of acquired firms. The third column models the determinants of the probability of being an acquiring firm, relative to the set of stable (non-takeover) firms. All data are measured in the year immediately preceding the takeover event, with one observation per firm. Although there are many significant coefficients in columns 2 and 3, we will only comment those that shed light on the sources of differences between taken over and taking over firms as shown by significant coefficients in column 1 .

The comparison of acquired with acquiring firms suggests that there is little to distinguish the hiring or compensation policies of the two sorts of firms, with the only difference in employment policy being that acquired firms tend to have fewer skilled blue collar workers (the share of white collar workers being the reference category), while the only difference in compensation can be found in a lower average residual for employees of acquired firms in the pre-transaction period. Column 3 suggests that former effect is primarily due to acquired firms having significantly lower shares of skilled blue collar workers than control firms, although acquiring firms also seem to have (insignificantly) fewer skilled blue collar workers as well. The latter effect is more difficult to explain by construction, since it corresponds to the residual from a regression in which most easily interpretable coefficients, individual fixed effects, firm fixed effects and firm-specific seniority effects already appear.

Perhaps surprisingly, both acquired and acquiring firms reward seniority better than non-takeover firms, and this similarity in coefficient sign with respect to non takeover firms appears to be applicable to a wider range of variables than simply those describing compensation policy. In fact, there are more coefficients that distinguish acquired and acquiring firms from non-takeover firms (columns 3 and 4) and these coefficients tend to be of similar sign; in fact, they are always of the same 
sign whenever a coefficient is significant for either acquired or acquiring firms. This general result suggests that firms involved in takeover activity tend to be quite different from firms that do not experience any takeover activity over the sample period. Such an observation may render identification of potential targets and acquirers easier for employment authorities, since these sorts of firms seem to be qualitatively different from stable, non-takeover firms.

Concerning the controls for differences in firm accounts, we find several sources of differences between acquired and acquiring firms. Taken over firms tend to be smaller and (insignificantly) more indebted than acquiring firms, yet they earn a higher return on assets than acquiring firms that are comparable on other dimensions. These results are consistent with the "costly capital" approach to modeling mergers and acquisitions, in that it appears that smaller, more profitable yet more indebted firms are likely to be acquired by larger, less profitable yet less indebted buyers. On the other hand, it is hard to see these results as consistent with the idea that the acquisitions are undertaken for economies of scale reasons as a the largest efficiency gains are to be had when large firms merge with each other, whereas neither acquiring nor acquired firms are significantly larger than non takeover firms on either the employment or assets dimension.

\section{Who Stays, Who Goes?}

Having addressed the issue of which firms are subject to takeovers and which firms undertake them, we now turn to the question of which employees are retained after the takeover occurs. This is likely to be a key concern of employment authorities, since they can anticipate any required reallocation of resources necessary 
to help workers that separate from their employers as a result of the takeover. Also, the Jensen and Meckling (1976) approach in the economics literature suggests that inadequate human resource management policies could lead an acquiring firm to lay off, either selectively or en masse, the employees of the acquired firm. Other theories of takeovers, in particular those stressing synergies or increasing returns to scale, would also suggest that combining several firms into one could lead to efficiency gains through a reduction in the resources (including employees) required to maintain the combined level of production. These theories do not necessarily imply that all layoffs (and even less all separations) will occur in the acquired firm, unlike the Jensen and Meckling (1976) approach, which is reassuring since the results in table 2 suggest that there is relatively little to distinguish the work forces of acquired and acquiring firms ex ante. Lastly, institutional constraints such as advance notice restrictions, collective bargaining agreement layoff rules, severance pay calculation formulae and the possibility of voluntary departures may affect the optimal dynamic labor force adjustment path and alter the composition of those separations in a manner that would be suboptimal in the absence of such constraints but corresponds to the best policy available given the existing economic environment.

\subsection{Where Do the Separations Occur?}

As noted above, workers may leave the new entity post-transaction for a variety of reasons, but in order to distinguish between these theories it is useful to know in which of the preexisting firms each worker was employed. In particular, if acquiring firms aim to improve the profitability of the ex-post entity by proceeding with modifications in the acquired firm, and if acquiring firms can observe the composition of the acquired firm's workforce after the transaction, then one would 
expect to see the majority of separations in the new entity coming from employees previously employed by the acquired firm, whereas if the reasoning involves synergies or economies of scale one might expect to see separations more evenly distributed across the ex-employees of the preexisting firms.

Figure 1 shows the probability of continued employment (Kaplan-Meier survivor functions stratified by type of employer) in the years following the takeover, for the employees of the acquired and of the acquiring firm as well as employees of non-takeover firms (with 2 standard-deviation confidence intervals drawn on either side of each curve). What is most remarkable about this figure is that firms involved in takeover activity, as suggested by table 2, seem to be quite different from nontakeover firms. In particular, the probability of continued employment is significantly lower for employees of non-takeover firms at any horizon. ${ }^{11}$ This result suggests that employees in non-takeover firms may not be the best comparison group for employees in takeover firms. Part of this difference may be related to the difficulty of proceeding with mass layoffs in France relative to individual layoffs, in particular the extra advance notice time implicit in the administrative procedures required to proceed with such work force adjustments (Margolis, 2002). Nevertheless, from the point of view of employment services, it appears that there is less reason to be concerned about employees of firms involved in takeover activity than of employees in non-takeover firms. ${ }^{12}$

\footnotetext{
${ }^{11}$ For these firms, we consider each individual at each date of employment and see how many years after the given date the individual remains employed. Thus each individual employed in a non-takeover firm contributes multiple observations to the construction of these graphs, with the earliest observed individuals and the longest tenure individuals making the largest contribution. This latter result makes the observation of a lower survivor rate for individuals in non-takeover firms even more surprising.

${ }^{12}$ Recall that we are only considering the probability of continued employment, and as such we do not know whether individuals transit disproportionately to unemployment or to other employers when considering the ex-employees of each type of firm. That said, the literature on displaced workers in France (Margolis, 2002) suggests that there is a significantly higher rate of direct employer-toemployer mobility for workers who separate from their employer within 2 years of when their employer disappears than those who separate from their employer at other times. Since acquired
} 
When focusing on firms involved in takeover activity, there do appear to be differences in continued employment probabilities in the short term (up to 3 years after takeover), but these differences become insignificant in the medium term (5 years after takeover). On the other hand, in the short term it is clear that the employees of the acquired firm remain employed with the new entity with a much lower probability than employees of the acquiring firm. These results suggest that more restructuring (in terms of voluntary and involuntary departures) is taking place up front within the workforce of the acquired firm than with that of the acquiring firm, whereas once the acquiring firm has sorted through the workers of the firm it acquired (and this takes several years), it begins to looks for synergies by making reductions in its own workforce.

Figure 2 provides the same sort of comparison, but further decomposing the sample by primary sector of activity (manufacturing or services). This figure shows that the results in figure 1 are driven primarily by the manufacturing sector, as the difference in the probability of continued employment between acquired and acquiring firms is much larger here than in the services sector. Employees of acquiring firms in manufacturing are, as with the average, the ones who last the longest with the new entity after the transaction. On the other hand, there is no significant difference in the probability of continued employment between acquired and acquiring firms in the services sector for any length of time post transaction, suggesting that there is relatively little to differentiate to workforces of the firms on either side of the transaction in this sector.

The overall lower continued employment probability in the manufacturing sector is likely due to the fact that manufacturing is becoming less and less important differences in continued employment probability presented here imply. 
in the French economy, as in most other developed economies, and thus continued employment in such firms is less likely than in service sector firms independent of any merger and acquisition activity. On the other hand, the differences in the relation between short and medium term effects across sectors appears at least partially due to the imprecise measurement of these effects in the services sector. Beyond that observation, since average seniority is higher in manufacturing than in services (11.9 years versus 7.7 years in the year preceding the takeover), it may be the case that it is easier to adjust the acquiring firm's workforce in the short term in the services sector than in the manufacturing sector, thereby reducing the gap in the short term in continued employment probability between acquired and acquiring service sector firms relative to the same gap in manufacturing firms.

Figure 3 looks at the differences in continued employment rates decomposed by whether the acquired and acquiring firms were operating in the same narrow (4digit) sector prior to the transaction or not. This figure makes it dramatically clear that the vast majority of the differences found in figures 1 and 2 are driven by the much lower continued employment probabilities of individuals whose employer was acquired by a firm from a different 4-digit industry. In fact, there are no significant differences at any date for firms in the same 4-digit industry, implying perhaps that most of the changes in behavior that take place after the transaction occur on the product market and not the labor market, as would be suggested by the game-theoretic models of takeovers based on market structure considerations. ${ }^{13}$ On the other hand, if a firm in one 4-digit industry is going to acquire another firm in another 4-digit industry, the reasoning cannot be purely product-market based since they do not

\footnotetext{
${ }^{13}$ In these models, the firms in the same sector merge for product market reasons and thus one would not expect to see any particular differences in the continued employment probability between the participants in the merger or acquisition, although total employment across the two preexisting firms may fall in the new entity if the optimal policy ex post involves restricting output. Such a productmarket based explanation is not pertinent for mergers between firms in different industries.
} 
operate in the same product market; the acquirer must expect to be able to reap significant productivity gains through restructuring the acquired firm, ${ }^{14}$ in particular since it has little experience a priori with running a firm in the other industry and thus may have difficulty financing the transaction if the sole motivation were to be based on product market strategy.

\subsection{Which Employees Stay and Which Go?}

The descriptive analysis above is only partially informative as to the importance of having previously been employed in the acquired or acquiring firm since these firms may differ ex ante in the composition of their workforces (and the employees of both sorts of takeover firms may differ from those of control firms) and the different continued employment rates may just be reflecting differential hazard rates of individuals with different characteristics. As a result, one needs to control for the different characteristics and, in particular, evaluate whether certain characteristics are more strongly associated with continued employment in acquired or acquiring firms, relative to non-takeover firms.

In this light, table 3 presents logit regressions of the probability that a person employed in the year preceding the takeover $(t-1)$ will still be employed in years $t+1$, $t+2$ and $t+5$ following the takeover. The control variables are all measured in the year preceding the takeover and table 3 also presents the share of individuals that, given presence in a particular year in a non-takeover firm, are still with that firm 2, 3

\footnotetext{
${ }^{14} \mathrm{We}$ are unable to examine explanations for takeovers based on vertical integration per se in our data, since there is no information on between-firm relations other than asset transfers. One could potentially look for targeted reductions in employment in purchasing or sales departments as indicative of such motivations, but alternative explanations (notably returns-to-scale based arguments) would lead to similar empirical implications. The results in section 6.2 below that look at how separations are distributed by broad occupational category are roughly consistent with these explanations, although it must be remembered that the gains to vertical integration must exceed the costs of the transaction in order for this to be a valid justification for the takeover.
} 
and 6 years later. These latter figures are provided as a reference for evaluating the importance of separations in the each type of firm.

Table 3 suggests that, whereas there is relatively little to distinguish acquired from acquiring firms in terms of workforce structure in the years preceding the takeover (consistent with the idea that such characteristics are unobservable and thus can not form the basis for a takeover decision), there is an important selection of workers taking place following the transaction. Certain sorts of workers are disproportionately retained and, almost everywhere, when a characteristic significantly affects retention in both sorts of firms, the sign is the same. For example, it appears that younger workers disproportionately separate from both acquired and acquiring firms in the year following the takeover, whereas older workers are significantly less likely to still be employed 3 years after any given date when the employer was not involved in any takeover activity. ${ }^{15}$

Table 3 makes it clear that human resource management policy is one of the first, and most important, aspects to be changed in the post-transaction period. In particular, the newly formed entity keeps the "best" workers, be they defined by the market value of their observable or unobservable fixed characteristics (the coefficient on the returns to observable time-varying individual specific characteristics, $\left(x_{i t}-\mu_{x}\right) \hat{\beta}$ in equation (1), are negative but rarely significant), and the others leave. Likewise, it appears that the least senior workers are the first to go, and the early departures by recent pre-takeover hires are not offset by increased medium-term departures of workers with more seniority. ${ }^{16}$ Skilled blue collar workers are

\footnotetext{
15 This result is not simply a retirement effect (older people leaving with a higher probability than younger people in the absence of takeover activity) as the age coefficient becomes significantly positive (instead of negative) for 7 years after any chosen date.

${ }^{16}$ Fallick (1996) notes that more senior workers are less likely to be displaced in any setting, including those where takeover are not involved. Again, this may be related to collective bargaining agreements
} 
increasingly disproportionately represented among those who stay on with both sorts of firms after the takeover, which may suggest a shift in the production technology. ${ }^{17}$

In terms of compensation policy, it appears that workers who were previously employed in relatively more generous firms, both in terms of starting wages and seniority returns, that were taken over are more likely to stay with the post-takeover firm, relative to those whose pre-takeover firm was stingier. On the other hand, despite a medium-term (5 years after takeover) variation in the same direction, ${ }^{18}$ those individuals employed by acquiring firms whose compensation policy was relatively less generous in terms of seniority returns are the more likely to stay. Since table 2 shows that acquired firms tend to have lower returns to seniority than acquiring firms ${ }^{19}$, such an effect may reflect incompatibilities in corporate cultures. $^{20}$ If individuals in the acquiring firm are used to deferred compensation incentive mechanisms or more intense firm-specific human capital investment while those in the acquired firm are used to less incentive pay or weaker investment in firm-specific human capital, the combination of the two opposing corporate cultures may induce some individuals to quit voluntarily. This clash will be less violent, on average, when the acquired firm rewards seniority relatively well and when the purchasing firm has a more moderate deferred compensation structure. In these settings, one might expect to see more individuals staying with the combined firm than in the opposite cases.

\footnotetext{
or the fact that severance pay (before supplements found in collective bargaining agreements) in France is indexed to job seniority, thus making more senior workers more expensive to fire.

${ }^{17}$ Our results only control for the sector of activity at a relatively aggregated level, so there is still a margin for variation in technology across firms within sector.

${ }^{18}$ The changing signs of several coefficients with the length of the time horizon demonstrates the usefulness of allowing the specification flexibility of repeated logit models (see footnote 5).

${ }^{19}$ The difference is not significant, although the point estimate is quantitatively large.

${ }^{20}$ This interpretation is based on an analysis of level coefficients, a more appropriate direct test of this hypothesis would be to reestimate the models using the difference in firm specific seniority policies between acquired and acquiring firms. Aside from the fact that such a variable is not well defined for non takeover firms, such a test would be outside the objectives of this paper.
} 
The results concerning the remaining control variables are more or less expected. Employees of acquired firms with smaller workforces and more physical capital are more likely to separate post-takeover, while those of more profitable yet indebted acquired firms are more likely to stay. The results concerning the effect of productivity on continued employment are difficult to interpret, since they suggest that the workers of the most productive acquired firms survive in the short term while those of less productive acquired firms are overrepresented among medium-term survivors. This may suggest larger up-front layoffs at the less productive firms with increasing disillusion (and thereby voluntary departure) in the new entity of more productive workers (as measured by the value added per worker of their employer prior to the transaction). Most of the effects for acquiring firms are similar to those of acquired firms, although there are more coefficient sign-changes in the medium term than with acquired firms. This may be indicative of the rationalizing of workforces that seemed to be underlying the closing of the gap between acquired and acquiring firms in the medium term shown in figures 1-3.

\section{Conclusion}

This paper has characterized the types of workers and firms that are involved in merger and acquisition activity and has discussed the determinants of post-takeover employment. The focus has been on compensation and human resource management policies, as our data are drawn from several sources, including a linked employeremployee data set which makes these issues accessible. Acquired and acquiring firms were characterized in terms of their compensation policies and human resource management practices, as opposed to simply balance sheet data. Detailed analyses of which workers are most at risk of separating from their employer post takeover were 
also carried out, and the distribution of separations between acquired and acquiring firms was investigated.

French firms have been shown to behave essentially as predicted by economic theory concerning mergers and acquisitions. Some takeovers seem to be driven by exante perceptible differences in firm characteristics (the results seem slightly at odds with a strict economies of scale type argument but more favorable to a costly capital model of takeovers), although workforce composition and compensation policy do not seem to play an important role as they are typically ex ante unobservable in the event of a hostile takeover and thus, according to the managerial control model, cannot be used by outside firms to identify potential sources of efficiency gains. Analysis of post-transaction employment shows that workforce reorganizations performed by the new entity target similar types of workers in the acquired and acquiring firms, suggesting that acquiring firms may use the takeover event as a justification for undertaking a broader restructuring, integrating the acquired firm's employees into the new entity and keeping only the most appropriate workers from both firms.

What does all of this mean for employment authorities? The workers who leave the post-transaction entity can be characterized by their observable characteristics as well as their "market value" (a measure of unobservable characteristics). They tend to be younger, female and white-collar workers with low job tenure and characteristics (both education-related and unmeasured in the data) that give them low market value. With the exception of the overrepresentation of women, these characteristics describe the workers who also find it easiest to get new jobs following a mass layoff, ${ }^{21}$ which means that employment services may not need to be

\footnotetext{
21 See Margolis (2002) for a detailed analysis of the determinants of post-displacement nonemployment durations in France. To the best of our knowledge, no results exist on nonemployment durations post-displacement in France as a function of the market value of observable or unobservable individual specific characteristics.
} 
directed as intensely to employees laid off after a takeover since these workers are likely to be able to find new jobs relatively easily even in the absence of additional assistance. This could be a reflection of the efficiency of policies that have already been implemented in France to reduce the impact of mass layoffs. In particular, the French government's policies regarding worker protection and advance notice make it much easier to lay off individuals than groups, which could explain the lower continued employment probability in the non-takeover firms. In addition, the last-in, first-out aspect of some collective agreements, the indexation of severance pay to previous seniority and the possibility of voluntary separations among our reasons for ending continued employment could explain why we see an over-representation of workers whose reemployment probability is particularly high among those whose continued employment probability is particularly low.

It should be noted, however, that workers in acquired firms do indeed separate from their employers more frequently than those in acquiring firms in the short term, while this difference fades in the medium term. Both acquired and acquiring firms differ from non-takeover firms in observable ways and similar sorts of workers are laid off from both types of firms after a takeover, so employment agencies may be able to do some planning for separations before they occur by focusing on firms that are more likely to be involved in takeover activity. But the planning may not need much in terms of additional resources (with the exception of women, those workers whose educational or otherwise unobservable characteristics make them less desirable to the labor market and unskilled blue-collar workers from the acquiring firms) since the workers most likely to separate are also those who can find new jobs the quickest after a separation. 
In sum, although employment authorities may be tempted to consider mergers and acquisitions as particular risks for their activity, such fears may be exaggerated given the existing institutional environment. The empirical evidence suggests that firms involved in takeovers are somewhat less likely to separate from their workers than firms that do not participate in any takeover activity, that the majority of separations occur in firms that acquired by other companies outside of their narrow sector of activity and that the workers that do eventually separate from their pretakeover employers may not need much more help than the "typical" person who separates from his or her employer. Furthermore, since the firms involved in takeover activity distinguish themselves from non-takeover firms on similar dimensions, employment authorities that remain skeptical can still try to plan for the future by examining the financial statements of firms that are based in their jurisdictions and by focusing on the ones that are the most (or least) likely to participate in takeover activity. 


\section{Bibliography}

Abowd John M., Kramarz Francis, Margolis David N. (1999) High Wage Workers and High Wage Firms, Econometrica 67(2): 251-333

Bertrand Marianne, Mullainathan Sendhil (2003) Enjoying the Quiet Life? Corporate Governance and Managerial Preferences, Journal of Political Economy 111(5): 1043-1075

Borenstein Severin (1990) Airline Mergers, Airport Dominance and Market Power, American Economic Review 80(2): 400-404

Bradley Michael, Desai Anand, Kim E. Han (1983) The Rationale Behind Interfirm Tender Offers: Information or Synergy? Journal of Financial Economics, 11(1-4): 183-206

Brown Charles, Medoff James L. (1988) The Impact of Firm Acquisitions on Labor, in Auerbach A. (ed) Corporate Takeovers: Causes and Consequences, 343 pp. University of Chicago Press, Chicago London

Compte Olivier, Jenny Frederic, Rey Patrick (2002) Capacity Constraints, Mergers and Collusion, European Economic Review 46(1): 1-29

Eckbo B. Espen (1983) Horizontal Mergers, Collusion and Stockholder Wealth, Journal of Financial Economics 11(1-4): 241-273

Fallick Bruce C. (1996) A Review of the Recent Empirical Literature on Displaced Workers, Industrial and Labor Relations Review 50(1): 5-16

Gibbons Robert, Katz Lawrence F. (1991) Layoffs and Lemons, Journal of Labor Economics 9(4): 351-380 
Gokhale Jagadeesh, Groshen Erica L., Neumark David (1995) Do Hostile Takeovers Reduce Extramarginal Wage Payments? Review of Economics and Statistics 77(3): 470-485

INSEE (1995) Guide d'utilisation des fichiers SUSE 3. INSEE, Paris.

Jensen Michael (1984) Takeovers: Folklore and Science, Harvard Business Review 62(6): 109-121

Jensen Michael (1986) Agency Costs of Free Cash Flow, Corporate Finance and Takeovers, American Economic Review 76(2): 323-329

Jensen Michael (1988) Takeovers: Their Causes and Consequences, Journal of Economic Perspectives 2(1): 21-48

Jensen Michael, Meckling William (1976) Theory of the Firm: Managerial Behavior, Agency Costs and Ownership Structure, Journal of Financial Economics 3(4): $305-360$

Lazear Edward P. (1979) Why Is There Mandatory Retirement? Journal of Political Economy 87(6): 1261-1284

Margolis David N. (1996) Cohort Effects and Returns to Seniority in France, Annales d'Economie et de Statistique, 0(41-42): 443-464

Margolis David N. (2002) Licenciements collectifs et durée entre deux emplois, Economie et Statistique 0(351) : 65-85

Margolis David N., Simonnet Véronique (2002) Technical/Professional versus General Education, Labor Market Networks and Labor Market Outcomes, International Journal of Manpower 23(5): 471-492

Manne Henry (1965) Mergers and the Market for Corporate Control, Journal of Political Economy 73(2): 110-120 
Matsusaka John G. (1993) Takeover Motives during the Conglomerate Merger Wave, Rand Journal of Economics 24(3): 357-379 


\section{A Data Appendix}

This data appendix provides details on the individual data sets that are used in the creation of the merged sample that is the basis of the empirical analysis. Each component data set is discussed separately.

\section{A.1 The MDST Data}

The first, and most original, data set is called the Modification of Structure, or MDST, file. This file is part of the SUSE 3 system (INSEE, 1995) and although it began in 1986, this paper only exploits data from 1993 to 1999, which includes 12,226 observations involving 17,078 distinct firms.

The objective of the data collectors is to cover all asset transfers of a minimum size (see footnote 2), providing the identifier of the firm (or firms) that transferred away the assets and the identifier of the firm (or firms) that received the assets. Asset transfers are categorized according to the point of view of the transferring (cédante, or $\mathrm{CD}$ below) and receiving (bénéficiaire, or $\mathrm{BF}$ below) firm and a small number of variables (including the effective date of the transaction) concerning the transaction are included with each record. Appendix Table 1 provides a breakdown of the different types of asset transfers covered by the MDST data. These data are used to date transactions, identify taken over and taking over firms and to know the identifier of the successor firm in any such transaction. In the interest of generating cleanly interpretable results, all firms that were involved in more than one takeover during the 1991-1999 period covered by the data were eliminated from the analyses. ${ }^{22}$

\footnotetext{
${ }^{22}$ These firms are not treated as BF or CD firms in our analyses, and thus the observations associated with individuals employed by these firms do not enter into our calculations as being in taken over or
} 
The analysis undertaken here focuses on transactions classified as either mergers or acquisitions, which corresponds to any of the following codes in appendix table 1: 23,31 or 33 for the transferring enterprise; 24 or 43 for the receiving enterprise. The effective date of the transaction, as opposed to the announcement date, is used for dating purposes as the acquiring firm can only directly influence managerial decisions after the transaction becomes effective. ${ }^{23}$ All firms that are listed as transferring firms in transactions defined by one of the above-listed codes are considered to be acquired and all firms for which the firm identifier is listed as the receiving firm are considered to be acquiring firms. One implication of this strategy is that, in a true "merger of equals", the acquiring firm will not have existed prior to the transaction. ${ }^{24}$ In all other cases, one of the pre-existing firms' identifiers is maintained after the transaction and this firm is considered to be the acquiring firm. Individuals who were employed by an acquired firm prior to the transaction and by its acquiring firm after the transaction are considered to have stayed with the new entity throughout the takeover. Firms involved in MDST activity that do not involve any of the aforementioned codes are not considered as having been involved in a merger or acquisition, and thus appear in the control (non takeover firms) group. ${ }^{25}$

taking over firms. This exclusion restriction eliminates 13 percent of the firm identifiers in the MDST sample. However, if an individual was employed by a firm whose only MDST activity was to have been taken over by another firm, and the acquiring firm had undertaken several MDST transactions, the post-takeover data is retained for the analyses.

${ }^{23}$ Most stock-market based analyses of takeovers attempt to focus on announcement dates, as the market factors expected future decisions into the price at that point in time, and thus one avoids having a biased estimate of the pre-takeover price. Apart from the fact that this variable is more often missing than the effective date (which is available for all records in the data), it is not relevant for the means by which this paper evaluates the different theoretical models.

${ }^{24}$ Note that, in this case, a single transaction will generate several MDST records, one for each premerger firm with that firm's identifier listed as the CD firm. The identifier listed as the BF firm in each of these records will be the same, and will correspond to the identifier of the (newly created) firm that springs from the merger. The fact that all of the records correspond to a single transaction can be established by their sharing a common transaction identification code.

${ }^{25}$ The case of partial divestitures could potentially be added to the set of firms classed as takeover firms, but the decision was made explicitly not to do so for two reasons. First, some employees of the firm that divests itself of a portion of its activity will continue to be employed after the transaction in the CD firm, which contaminates the set of CD firms used in the analysis in section 5. Second, there is 


\section{A.2 The FUTE Data}

The second data source is called the FUTE data, and is also drawn from the SUSE 3 system (INSEE, 1995). The FUTE data set contains all of the information available on a firm's balance sheet, income statement and statement of flow of funds. In addition, it contains additional variables drawn from the Annual Enterprise Survey (EAE), in particular concerning employment, and information drawn from the firm's tax returns. This data set provides the largest number of firm variables in the SUSE 3 system, although it does not sample all firms. ${ }^{26}$ The data cover the period 1989-2000, which generates 1,225,700 observations, of which 922,500 come from the 1991-1999 period common with the MDST data. This amounts to roughly 102,500 firms per year. Given the thresholds of the MDST data, all firms not in the "sample" (see appendix footnote 4) will appear in MDST when taken over, although it is possible that some "sample" firms will be excluded in the case of a takeover due to a lack of assets. Conversely, there may be MDST firms that are not covered by the FUTE as they are not part of the "sample" and are too small to be non-"sample" firms.

The FUTE data provide the control variables that we use to control for other reasons for takeovers besides compensation policies or human resource management practices. In particular, the analysis uses transformations of the following variables:

a clear selection issue (in the Gibbons and Katz (1991) sense) that intervenes in this context, as a firm that is about to divest itself of a division make seek to transfer its best workers to other divisions prior to the divestiture. For both of these reasons, attention is thus restricted to full mergers or acquisitions.

${ }^{26}$ The sampling scheme depends on whether the data was part of the "sample" of firms whose data is sent to INSEE before the full treatment of all firms (for the purpose of generating advanced indicators) or not. A firm that is part of the "sample" appears in the FUTE data if it has more than 10 employees, more than 3.5M French Francs in sales or more than 5M French Francs in assets. The non-sample firms are included in the FUTE if they have over 20 employees, over $100 \mathrm{M}$ francs in sales or over $200 \mathrm{M}$ francs in assets. Although the "sample" covered less than 5\% of all French enterprises in 1992, it represented $76 \%$ of employment and $82 \%$ of sales by all French firms (INSEE, 1995). 
total assets, total fixed assets, depreciation and amortization, total debt, value added and total employment.

\section{A.3 The DADS-EDP Data}

The final two data sources are the Annual Declarations of Social Data (DADS) and the Permanent Demographic Sample (EDP). A detailed description of both of these data sets and their basic construction is provided in the data appendix to Abowd, Kramarz and Margolis (1999). The data used here cover the period from 1991 through 1999, although exploitable panel data exist as far back as 1976.

The DADS data used here constitute a $1 / 25^{\text {th }}$ random sample of the French population. The data consist of employer records filed by firms with the government on behalf of employees for the purposes of calculating retirement benefits (among other things), and thus contain identifiers for both the individual and the employing firm. The data provide information on total gross earnings and number of days worked during the course of each year for each employer for whom a sampled individual worked, as well as information on the age and sex of the individual, the départment (geographic region) in which the person worked, the sector of the employer and the occupation and type of job (e.g. full or part time employment) held by the employee. They also provide the first and last days worked during each year, a criterion upon which we base our analysis sample. As each employment spell (other than non-salaried self-employment and central government employment) generates an observation in the DADS, these data not only provide us with a large source of linked employer-employee data, but a potentially a 24 year panel on the individual side. ${ }^{27}$

\footnotetext{
${ }^{27}$ The dimension of the panel on the firm side depends on the appearance of a sampled individual in a firm. Firms with at least one sample individual in each of the years of our data will also be available for
} 
The linked panel aspect is also what allows us to calculate job seniority for each sample individual. ${ }^{28}$

One weakness of the DADS data is the lack of individual specific information, notably the absence of data on education. The EDP data, which cover roughly $1 / 10$ of the individuals in the DADS data, help to remedy this situation. The EDP data consist of information drawn from census reports, birth reports, marriage declarations and death reports in which a sample individual can be identified. The paper uses the information on highest degree obtained (available in the census reports) to measure education for individuals in the DADS-EDP overlap, and it imputes education to the remaining $9 / 10$ of the sample on the basis of a multinomial logit model. ${ }^{29}$

26 years. Given the sampling scheme, if there were a purely random redistribution of individuals across firms each year, there would be a better than 50\% change that a firm with at least 17 employees will have at least one sample individual in any given year. Given that individuals tend not to switch employers every year, the probability of having a sample individual in year $t+1$ given the presence of such an individual in year $\mathrm{t}$ is significantly higher.

${ }^{28}$ Left-censoring of job spells is dealt with by estimation of the pre-sample job seniority using data drawn from yet another source, the Salary Structure Survey. See Abowd, Kramarz and Margolis (1999) for details.

${ }^{29}$ See Abowd, Kramarz and Margolis (1999) for details. Results of the multinomial logit estimation on the extended sample are available upon request. 
Table 1

Descriptive Statistics by Sample (Means with Standard Deviations in Parentheses)

\begin{tabular}{|c|c|c|c|c|c|c|}
\hline Variable & Full Merged & $\begin{array}{l}\text { Multiple } \\
\text { Takeover }\end{array}$ & $\begin{array}{c}\text { Analysis } \\
\text { Sample }\end{array}$ & Taken Over & Taking Over & No Takeover \\
\hline \multicolumn{7}{|l|}{ Compensation Policy } \\
\hline Firm-Specific Fixed Effect & $\begin{array}{c}-0.2611 \\
(1.1396)\end{array}$ & $\begin{array}{c}-0.4987 \\
(1.0195)\end{array}$ & $\begin{array}{c}-0.2432 \\
(1.1456)\end{array}$ & $\begin{array}{l}-0.1873 \\
(1.1079)\end{array}$ & $\begin{array}{c}-0.2658 \\
(1.0712)\end{array}$ & $\begin{array}{c}-0.2445 \\
(1.1611)\end{array}$ \\
\hline Firm-Specific Seniority Returns & $\begin{array}{c}0.0299 \\
(0.0972)\end{array}$ & $\begin{array}{c}0.0378 \\
(0.0703)\end{array}$ & $\begin{array}{c}0.0301 \\
(0.0920)\end{array}$ & $\begin{array}{c}0.0302 \\
(0.0962)\end{array}$ & $\begin{array}{c}0.0337 \\
(0.0710)\end{array}$ & $\begin{array}{c}0.0295 \\
(0.0948)\end{array}$ \\
\hline Residual from Earnings Decomposition & $\begin{array}{c}0.4516 \\
(1.3730) \\
\end{array}$ & $\begin{array}{c}0.7658 \\
(1.2451) \\
\end{array}$ & $\begin{array}{c}0.4332 \\
(1.3803) \\
\end{array}$ & $\begin{array}{c}0.3262 \\
(1.4067) \\
\end{array}$ & $\begin{array}{c}0.4807 \\
(1.2963) \\
\end{array}$ & $\begin{array}{c}0.4348 \\
(1.3914) \\
\end{array}$ \\
\hline \multicolumn{7}{|l|}{ Human Resource Management Policy } \\
\hline Male & $\begin{array}{c}0.6290 \\
(0.4831)\end{array}$ & $\begin{array}{c}0.6298 \\
(0.4829)\end{array}$ & $\begin{array}{c}0.6323 \\
(0.4822)\end{array}$ & $\begin{array}{c}0.6464 \\
(0.4781)\end{array}$ & $\begin{array}{c}0.6330 \\
(0.4820)\end{array}$ & $\begin{array}{c}0.6309 \\
(0.4826)\end{array}$ \\
\hline Potential Experience & $\begin{array}{c}35.4577 \\
(186.9056)\end{array}$ & $\begin{array}{c}36.7614 \\
(191.3381)\end{array}$ & $\begin{array}{c}35.0934 \\
(185.2302)\end{array}$ & $\begin{array}{c}29.1403 \\
(158.7712)\end{array}$ & $\begin{array}{c}39.7161 \\
(202.8794)\end{array}$ & $\begin{array}{c}34.8375 \\
(184.2545)\end{array}$ \\
\hline Job Seniority & $\begin{array}{c}5.9611 \\
(7.5484)\end{array}$ & $\begin{array}{c}6.1295 \\
(7.6995)\end{array}$ & $\begin{array}{c}6.0171 \\
(7.5685)\end{array}$ & $\begin{array}{c}4.7777 \\
(6.4643)\end{array}$ & $\begin{array}{c}7.4879 \\
(8.9128)\end{array}$ & $\begin{array}{c}5.8759 \\
(7.3710)\end{array}$ \\
\hline Skilled Blue Collar & $\begin{array}{c}0.2126 \\
(0.4092)\end{array}$ & $\begin{array}{c}0.1625 \\
(0.3689)\end{array}$ & $\begin{array}{c}0.2164 \\
(0.4118)\end{array}$ & $\begin{array}{c}0.2170 \\
(0.4122)\end{array}$ & $\begin{array}{c}0.1968 \\
(0.3976)\end{array}$ & $\begin{array}{c}0.2197 \\
(0.4141)\end{array}$ \\
\hline Unskilled Blue Collar & $\begin{array}{c}0.2467 \\
(0.4311)\end{array}$ & $\begin{array}{c}0.1720 \\
(0.3774)\end{array}$ & $\begin{array}{c}0.2500 \\
(0.4330)\end{array}$ & $\begin{array}{c}0.2684 \\
(0.4432)\end{array}$ & $\begin{array}{c}0.2074 \\
(0.4054)\end{array}$ & $\begin{array}{c}0.2557 \\
(0.4363)\end{array}$ \\
\hline No Education & $\begin{array}{c}0.2896 \\
(0.1404)\end{array}$ & $\begin{array}{c}0.2784 \\
(0.1397)\end{array}$ & $\begin{array}{c}0.2899 \\
(0.1404)\end{array}$ & $\begin{array}{c}0.2927 \\
(0.1378)\end{array}$ & $\begin{array}{c}0.2808 \\
(0.1407)\end{array}$ & $\begin{array}{c}0.2913 \\
(0.1405)\end{array}$ \\
\hline $\begin{array}{l}\text { Vocational-Technical School } \\
\text { (Pre-High School Level) }\end{array}$ & $\begin{array}{c}0.2027 \\
(0.0844)\end{array}$ & $\begin{array}{c}0.1997 \\
(0.0846)\end{array}$ & $\begin{array}{c}0.2031 \\
(0.0844)\end{array}$ & $\begin{array}{c}0.2028 \\
(0.0825)\end{array}$ & $\begin{array}{c}0.2046 \\
(0.0857)\end{array}$ & $\begin{array}{c}0.2028 \\
(0.0843)\end{array}$ \\
\hline Baccalauréat (High School Diploma) & $\begin{array}{c}0.0645 \\
(0.0231)\end{array}$ & $\begin{array}{c}0.0664 \\
(0.0236)\end{array}$ & $\begin{array}{c}0.0644 \\
(0.0231)\end{array}$ & $\begin{array}{c}0.0644 \\
(0.0227)\end{array}$ & $\begin{array}{c}0.0650 \\
(0.0238)\end{array}$ & $\begin{array}{c}0.0643 \\
(0.0230)\end{array}$ \\
\hline 2 year post-High School Education & $\begin{array}{c}0.0445 \\
(0.0427)\end{array}$ & $\begin{array}{c}0.0475 \\
(0.0445)\end{array}$ & $\begin{array}{c}0.0445 \\
(0.0427)\end{array}$ & $\begin{array}{c}0.0439 \\
(0.0422)\end{array}$ & $\begin{array}{c}0.0459 \\
(0.0435)\end{array}$ & $\begin{array}{c}0.0443 \\
(0.0426)\end{array}$ \\
\hline Advanced Tertiary Education & $\begin{array}{c}0.0289 \\
(0.0464)\end{array}$ & $\begin{array}{c}0.0334 \\
(0.0540)\end{array}$ & $\begin{array}{c}0.0288 \\
(0.0462)\end{array}$ & $\begin{array}{c}0.0281 \\
(0.0460)\end{array}$ & $\begin{array}{c}0.0303 \\
(0.0461)\end{array}$ & $\begin{array}{c}0.0286 \\
(0.0462)\end{array}$ \\
\hline $\begin{array}{l}\text { Return to Fixed Unobservable } \\
\text { Individul-Specific Christer }\end{array}$ & $\begin{array}{c}15.7710 \\
(21817900)\end{array}$ & $\begin{array}{c}-13.9392 \\
(2205.9300)\end{array}$ & $\begin{array}{c}15.4657 \\
(21707900)\end{array}$ & $\begin{array}{c}74.3417 \\
(16510200)\end{array}$ & $\begin{array}{l}-10.3205 \\
(23620500)\end{array}$ & $\begin{array}{c}14.5563 \\
(21778700)\end{array}$ \\
\hline Returns to Education & $\begin{array}{l}(2181.7900) \\
-205.2432 \\
(905.6670)\end{array}$ & $\begin{array}{c}(2205.9300) \\
-186.8339 \\
(934.5849)\end{array}$ & $\begin{array}{l}(2170.7900) \\
-202.0172 \\
(896.8371)\end{array}$ & $\begin{array}{c}(1651.0200) \\
-175.3906 \\
(802.0135)\end{array}$ & $\begin{array}{c}(2362.0500) \\
-217.3100 \\
(945.1868)\end{array}$ & $\begin{array}{c}(2177.8700) \\
-201.7999 \\
(896.3797)\end{array}$ \\
\hline $\begin{array}{l}\text { Returns to Other Observable (Time-Varying) } \\
\text { Individual-Specific Characterisitcs }\end{array}$ & $\begin{array}{c}291.2986 \\
(2910.3200)\end{array}$ & $\begin{array}{c}303.5613 \\
(2960.5600)\end{array}$ & $\begin{array}{c}286.3179 \\
(2886.9600)\end{array}$ & $\begin{array}{c}210.4459 \\
(2483.2500)\end{array}$ & $\begin{array}{c}343.6943 \\
(3156.2800)\end{array}$ & $\begin{array}{c}283.3230 \\
(2872.2700)\end{array}$ \\
\hline \multicolumn{7}{|l|}{ Firm Accounts } \\
\hline Total Employment & $\begin{array}{c}8700.4800 \\
(28785.0000)\end{array}$ & $\begin{array}{c}6314.5700 \\
(10983.3600)\end{array}$ & $\begin{array}{c}9128.7200 \\
(30465.9400)\end{array}$ & $\begin{array}{c}835.9185 \\
(2386.1000)\end{array}$ & $\begin{array}{c}18869.6500 \\
(39203.3000)\end{array}$ & $\begin{array}{c}8201.1600 \\
(29725.0600)\end{array}$ \\
\hline Fixed Assets Net of Depreciation and Amortization & $\begin{array}{c}2.2130 \mathrm{E}+07 \\
(1.0224 \mathrm{E}+08)\end{array}$ & $\begin{array}{c}9.4257 \mathrm{E}+06 \\
(3.1424 \mathrm{E}+07)\end{array}$ & $\begin{array}{c}2.4285 \mathrm{E}+07 \\
(1.0919 \mathrm{E}+08)\end{array}$ & $\begin{array}{c}1.2086 \mathrm{E}+06 \\
(9.4251 \mathrm{E}+06)\end{array}$ & $\begin{array}{c}9.2926 \mathrm{E}+07 \\
(2.2234 \mathrm{E}+08)\end{array}$ & $\begin{array}{c}1.4519 \mathrm{E}+07 \\
(7.4537 \mathrm{E}+07)\end{array}$ \\
\hline Pct. Increase in Value of Fixed Assets ( $t-1$ to $t)$ & $\begin{array}{c}430.4765 \\
(32484.0500)\end{array}$ & $\begin{array}{c}2423.5600 \\
(100282.2800)\end{array}$ & $\begin{array}{c}272.4715 \\
(17107.4500)\end{array}$ & $\begin{array}{c}134.9265 \\
(2380.8500)\end{array}$ & $\begin{array}{c}705.0423 \\
(36952.1200)\end{array}$ & $\begin{array}{c}209.0060 \\
(11414.0300)\end{array}$ \\
\hline Total Debt/Total Assets & $\begin{array}{c}0.7247 \\
(1.7081)\end{array}$ & $\begin{array}{c}0.6733 \\
(0.1884)\end{array}$ & $\begin{array}{c}0.7191 \\
(0.6267)\end{array}$ & $\begin{array}{c}0.7358 \\
(0.2813)\end{array}$ & $\begin{array}{c}0.6923 \\
(0.3705)\end{array}$ & $\begin{array}{c}0.7222 \\
(0.6826)\end{array}$ \\
\hline Return on Assets & $\begin{array}{c}0.0317 \\
(1.7335)\end{array}$ & $\begin{array}{c}0.0278 \\
(0.0673)\end{array}$ & $\begin{array}{c}0.0352 \\
(0.7050)\end{array}$ & $\begin{array}{c}0.0387 \\
(0.1331)\end{array}$ & $\begin{array}{c}0.0311 \\
(0.0901)\end{array}$ & $\begin{array}{c}0.0356 \\
(0.7915)\end{array}$ \\
\hline Value Added per Worker & $\begin{array}{c}390.3440 \\
(9407.1400)\end{array}$ & $\begin{array}{c}1426.0100 \\
(25164.8500) \\
\end{array}$ & $\begin{array}{c}310.5028 \\
(6724.9500) \\
\end{array}$ & $\begin{array}{c}352.1327 \\
(6262.2600) \\
\end{array}$ & $\begin{array}{c}282.3146 \\
(1054.2400)\end{array}$ & $\begin{array}{c}311.5763 \\
(7307.8500) \\
\end{array}$ \\
\hline Number of Observations & 4592849 & 357392 & 3973079 & 287043 & 543601 & 3142435 \\
\hline $\begin{array}{l}\text { Notes: Standard deviations of point estimates for estimated var } \\
\text { individual-enterprise-year combination with data from at least } \\
\text { merged sample (column 1) is divided into } 3 \text { sub-samples: Mul } \\
\text { firms with at least } 8 \mathrm{MF} \text { in assets at least once between } 1993 \text { ar } \\
\text { Acquired firms (column 4), Acquiring firms (column 5) and N }\end{array}$ & $\begin{array}{l}\text { akeover firms (cc } \\
98 \text { and single-trar } \\
\text { keover firms with }\end{array}$ & $\begin{array}{l}\text { olumn 2), Non-tak } \\
\text { nsaction Acquired } \\
\text { at least } 8 \mathrm{MF} \text { in a }\end{array}$ & $\begin{array}{l}\text { over firms with les } \\
\text { and Acquiring firms } \\
\text { sets (column 6). }\end{array}$ & $\begin{array}{l}\text { s than } 8 \mathrm{MF} \text { in ass } \\
\text { (column } 3 \text { ). This }\end{array}$ & $\begin{array}{l}\text { tast (non shown) anc } \\
\text { latery is de }\end{array}$ & $\begin{array}{l}\text { ique } \\
\text { s. The full } \\
\text { d Non-takeover } \\
\text { ecomposed into }\end{array}$ \\
\hline
\end{tabular}


Table 2

Logit Regressions: Characterization of Firms Relative to MDST Activity (Coefficients with Standard Errors in Parentheses)

\begin{tabular}{|c|c|c|c|}
\hline $\begin{array}{l}\text { Probability Modeled } \\
\text { Comparison Group }\end{array}$ & $\begin{array}{c}\text { P(Acquired) } \\
\text { Acquiring Firms }\end{array}$ & $\begin{array}{l}\text { P(Acquired }) \\
\text { Control Firms }\end{array}$ & $\begin{array}{l}\mathrm{P} \text { (Acquiring) } \\
\text { Control Firms }\end{array}$ \\
\hline \multicolumn{4}{|l|}{ Human Resource Management } \\
\hline Male & $\begin{array}{r}-0.0460 \\
(0.0858)\end{array}$ & $\begin{array}{c}0.1591^{\text {**** }} \\
(0.0365)\end{array}$ & $\begin{array}{l}0.1917^{\text {**** }} \\
(0.0521)\end{array}$ \\
\hline Age & $\begin{array}{l}-0.0221 \\
(0.0159)\end{array}$ & $\begin{array}{r}0.0094 \\
(0.0089)\end{array}$ & $\begin{array}{r}0.0064 \\
(0.0090)\end{array}$ \\
\hline Job Seniority & $\begin{array}{l}-0.0055 \\
(0.0048)\end{array}$ & $\begin{array}{l}-0.0198^{\text {**** }} \\
(0.0022)\end{array}$ & $\begin{array}{l}-0.0224^{* * *} \\
(0.0030)\end{array}$ \\
\hline Skilled Blue Collar & $\begin{array}{l}-0.1784^{\text {** }} \\
(0.0803)\end{array}$ & $\begin{array}{l}-0.1999^{* * *} \\
(0.0352)\end{array}$ & $\begin{array}{r}-0.0661 \\
(0.0493)\end{array}$ \\
\hline Unskilled Blue Collar & $\begin{array}{r}-0.0256 \\
(0.0776)\end{array}$ & $\begin{array}{r}-0.0547 \\
(0.0336)\end{array}$ & $\begin{array}{r}-0.0556 \\
(0.0482)\end{array}$ \\
\hline Return to Fixed Unobservable & $1.57 \mathrm{E}-06$ & $1.900 \mathrm{E}-05$ & $1.230 \mathrm{E}-06$ \\
\hline Individual-Specific Characterisitcs & $(5.300 \mathrm{E}-05)$ & $(2.100 \mathrm{E}-05)$ & $(2.500 \mathrm{E}-05)$ \\
\hline Returns to Education & $\begin{array}{r}7.00 \mathrm{E}-06 \\
(1.170 \mathrm{E}-04)\end{array}$ & $\begin{array}{r}-3.000 \mathrm{E}-05 \\
(4.800 \mathrm{E}-05)\end{array}$ & $\begin{array}{r}8.593 \mathrm{E}-06 \\
(7.000 \mathrm{E}-05)\end{array}$ \\
\hline $\begin{array}{l}\text { Returns to Observable (Time-Varying) } \\
\text { Individual-Specific Characterisitcs } \\
\text { Compensation Policy }\end{array}$ & $\begin{array}{r}-5.700 \mathrm{E}-04 \\
(6.620 \mathrm{E}-04)\end{array}$ & $\begin{array}{r}-3.600 \mathrm{E}-04 \\
(2.500 \mathrm{E}-04)\end{array}$ & $\begin{array}{r}1.280 \mathrm{E}-04 \\
(4.010 \mathrm{E}-04)\end{array}$ \\
\hline Firm-Specific Fixed Effect & $\begin{array}{l}-0.1015 \\
(0.0682)\end{array}$ & $\begin{array}{l}-0.0709^{* *} \\
(0.0277)\end{array}$ & $\begin{array}{r}-0.0030 \\
(0.0399)\end{array}$ \\
\hline Firm-Specific Seniority Returns & $\begin{array}{r}-0.2344 \\
(0.2370)\end{array}$ & $\begin{array}{l}0.2887^{* *} \\
(0.1165)\end{array}$ & $\begin{array}{l}0.6306^{* * * *} \\
(0.1672)\end{array}$ \\
\hline Residual from Earnings Decomposition & $\begin{array}{l}-0.13311^{* * *} \\
(0.0669)\end{array}$ & $\begin{array}{l}-0.0818^{\text {**** }} \\
(0.0269)\end{array}$ & $\begin{array}{r}0.0218 \\
(0.0392)\end{array}$ \\
\hline \multicolumn{4}{|l|}{ Firm Accounts } \\
\hline Log(Total Employment) & $\begin{array}{r}0.4589 \\
(0.4410)\end{array}$ & $\begin{array}{r}0.0804 \\
(0.2079)\end{array}$ & $\begin{array}{r}-0.0125 \\
(0.2893)\end{array}$ \\
\hline Log(Value of Fixed Assets Net of Depreciation and Amortization) & $\begin{array}{l}-0.7321 * \\
(0.4411)\end{array}$ & $\begin{array}{r}0.1637 \\
(0.2077)\end{array}$ & $\begin{array}{r}0.4069 \\
(0.2892)\end{array}$ \\
\hline Percent Increase in the Value of Fixed Assets & $-3.580 \mathrm{E}-07$ & 6.621E-08 & 2.247E-07 \\
\hline Net of Depreciation and Amortization & $(1.780 \mathrm{E}-06)$ & $(1.045 \mathrm{E}-06)$ & $(3.101 \mathrm{E}-07)$ \\
\hline Log(Total Debt/Total Assets) & $\begin{array}{r}0.0181 \\
(0.0437)\end{array}$ & $\begin{array}{r}0.0249 \\
(0.0209)\end{array}$ & $\begin{array}{r}0.0282 \\
(0.0257)\end{array}$ \\
\hline $\log ($ Return on Assets $)$ & $\begin{array}{l}0.0517^{\text {**** }} \\
(0.0151)\end{array}$ & $\begin{array}{l}0.0453^{\text {*** }} \\
(0.0072)\end{array}$ & $\begin{array}{r}0.0064 \\
(0.0094)\end{array}$ \\
\hline Log(Value Added per Worker) & $\begin{array}{r}-0.0588 \\
(0.0495) \\
\end{array}$ & $\begin{array}{c}0.0830^{* * * *} \\
(0.0237)\end{array}$ & $\begin{array}{l}0.1408^{* * *} \\
(0.0301)\end{array}$ \\
\hline Log Likelihood & -3897.1845 & -15352.8675 & -8191.83 \\
\hline Pseudo-R Square (Rescaled) & 0.1445 & 0.125 & 0.1916 \\
\hline Number of Dependent Variable $=1$ Firms & 4536 & 4536 & 2210 \\
\hline Number of Firms & 6746 & 74807 & 72481 \\
\hline \multicolumn{4}{|c|}{$\begin{array}{l}\text { Sources: MDST, FUTE, DADS and EDP data and Author's Calculations. } \\
\text { Notes: All models also include controls for } 9 \text { observation years, } 10 \text { sectors, Paris region, } 8 \text { educational categories, age }{ }^{2} \text { age }^{3} \text { and age }^{4} \text {, } \\
\text { Log(capital-labor ratio), } \log (\text { sales/worker) and the interation of seniority with returns to seniority. *** indicates a coefficient significant at the } 1 \% \text { level, } \\
\text { *at the } 5 \% \text { level and }{ }^{*} \text { at the } 10 \% \text { level. }\end{array}$} \\
\hline
\end{tabular}


Table 3

Logit Regressions: Probability of Continued Employment

(Coefficients with Standard Errors in Parentheses)

\begin{tabular}{|c|c|c|c|c|c|c|c|c|c|}
\hline \multirow[b]{2}{*}{ Variable } & \multicolumn{3}{|c|}{ Acquired Firms } & \multicolumn{3}{|c|}{ Acquiring Firms } & \multicolumn{3}{|c|}{ Non-Takeover Firms } \\
\hline & 1 year after & 2 years after & 5 years after & 1 year after & 2 years after & 5 years after & 1 year after & 2 years after & 5 years after \\
\hline \multicolumn{10}{|l|}{ Human Resource Management } \\
\hline Male & $\begin{array}{c}0.6230^{* *} \\
(0.3135)\end{array}$ & $\begin{array}{c}0.8024^{\circ} \\
(0.4421)\end{array}$ & $\begin{array}{r}1.3165 \\
(1.0012)\end{array}$ & $\begin{array}{r}0.4441 \\
(0.3186)\end{array}$ & $\begin{array}{r}0.3413 \\
(0.3917)\end{array}$ & $\begin{array}{c}2.7088 \\
(1.0475)\end{array}$ & $\begin{array}{l}-0.1056 \cdots \\
(0.0313)\end{array}$ & $\begin{array}{l}-0.5188 \cdots \\
(0.0365)\end{array}$ & $\begin{array}{l}-0.9356 \\
(0.0625)\end{array}$ \\
\hline \multirow[t]{2}{*}{ Age } & $0.3728^{*}$ & 0.6409 & 1.3074 & $0.4639 "$ & 0.1450 & 0.7694 & $0.2600^{\cdots \cdots}$ & $-0.2911 \cdots$ & 1.1345 \\
\hline & $(0.1973)$ & $(0.2943)$ & $(0.6578)$ & $(0.2017)$ & $(0.2634)$ & $(0.6555)$ & $(0.0198)$ & $(0.0245)$ & $(0.0584)$ \\
\hline Job Seniority & $\begin{array}{l}0.02099^{\cdots} \\
(0.0021)\end{array}$ & $\begin{array}{l}0.0156^{\cdots \cdots} \\
(0.0026)\end{array}$ & $\begin{array}{r}0.0043 \\
(0.0057)\end{array}$ & $\begin{array}{l}0.0093^{* * * *} \\
(0.0020)\end{array}$ & $\begin{array}{l}0.0250 \cdots \\
(0.0025)\end{array}$ & $\begin{array}{c}0.0445 \\
(0.0058)\end{array}$ & $\begin{array}{l}0.0383^{\cdots \cdots} \\
(0.0002)\end{array}$ & $\begin{array}{l}0.0370^{\cdots \cdots} \\
(0.0003)\end{array}$ & $\begin{array}{l}0.0378^{\cdots \cdots} \\
(0.0004)\end{array}$ \\
\hline Skilled Blue Collar & $\begin{array}{l}0.0890 * \\
(0.0377)\end{array}$ & $\begin{array}{l}0.2114^{\cdots \cdots} \\
(0.0453)\end{array}$ & $\begin{array}{c}0.2917^{* * *} \\
(0.0937)\end{array}$ & $\begin{array}{r}-0.0436 \\
(0.0346)\end{array}$ & $\begin{array}{r}0.0335 \\
(0.0435)\end{array}$ & $\begin{array}{c}0.23355^{\circ *} \\
(0.0946)\end{array}$ & $\begin{array}{l}-0.01555^{\cdots \cdots} \\
(0.0039)\end{array}$ & $\begin{array}{l}0.0157^{\cdots \cdots} \\
(0.0042)\end{array}$ & $\begin{array}{l}0.0538^{\ldots \cdots} \\
(0.0065)\end{array}$ \\
\hline Unskilled Blue Collar & $\begin{array}{r}0.0292 \\
(0.0407)\end{array}$ & $\begin{array}{r}0.0734 \\
(0.0502)\end{array}$ & $\begin{array}{r}0.0970 \\
(0.1069)\end{array}$ & $\begin{array}{l}-0.1301, * * * \\
(0.0387)\end{array}$ & $\begin{array}{r}-0.0688 \\
(0.0482)\end{array}$ & $\begin{array}{c}-0.1905^{\circ} \\
(0.1115)\end{array}$ & $\begin{array}{l}-0.05777^{\cdots \cdots} \\
(0.0040)\end{array}$ & $\begin{array}{l}-0.04311^{\cdots} \\
(0.0045)\end{array}$ & $\begin{array}{r}0.0040 \\
(0.0070)\end{array}$ \\
\hline $\begin{array}{l}\text { Return to Fixed Unobservable } \\
\text { Individual-Specific Characterisitcs }\end{array}$ & $\begin{array}{l}0.1631 \\
(0.0299)\end{array}$ & $\begin{array}{l}0.3404 \\
(0.0408)\end{array}$ & $\begin{array}{c}0.38544^{* \cdots *} \\
(0.0969)\end{array}$ & $\begin{array}{l}0.1947^{* * *} \\
(0.0310)\end{array}$ & $\begin{array}{l}0.1719^{\cdots \cdots+} \\
(0.0386)\end{array}$ & $\begin{array}{c}0.2128 " * \\
(0.0960)\end{array}$ & $\begin{array}{l}0.24122^{\cdots \cdots} \\
(0.0028)\end{array}$ & $\begin{array}{l}0.2530 \cdots \\
(0.0032)\end{array}$ & $\begin{array}{c}0.2324 \\
(0.0050)\end{array}$ \\
\hline Returns to Education & $\begin{array}{l}0.1634 \cdots \\
(0.0299)\end{array}$ & $\begin{array}{l}0.3402 \cdots \\
(0.0408)\end{array}$ & $\begin{array}{c}0.3851 \\
(0.0969)\end{array}$ & $\begin{array}{l}0.19488^{* * *} \\
(0.0310)\end{array}$ & $\begin{array}{l}0.1721 \cdots \\
(0.0386)\end{array}$ & $\begin{array}{c}0.2130 " * \\
(0.0960)\end{array}$ & $\begin{array}{l}0.24111^{\cdots \cdots} \\
(0.0028)\end{array}$ & $\begin{array}{l}0.2529 \cdots \\
(0.0032)\end{array}$ & $\begin{array}{c}0.2322 \\
(0.0050)\end{array}$ \\
\hline $\begin{array}{l}\text { Returns to Observable (Time-Varying) } \\
\text { Individual-Specific Characterisitcs } \\
\text { Compensation Policy }\end{array}$ & $\begin{array}{r}-1.0999 \\
(1.0975)\end{array}$ & $\begin{array}{l}-3.5280 " \\
(1.5513)\end{array}$ & $\begin{array}{r}-5.4494 \\
(3.4497)\end{array}$ & $\begin{array}{r}-1.3130 \\
(1.1180)\end{array}$ & $\begin{array}{r}-0.8246 \\
(1.3845)\end{array}$ & $\begin{array}{c}-8.2198 \cdots \\
(3.5221)\end{array}$ & $\begin{array}{l}-0.2144^{*} \\
(0.1103)\end{array}$ & $\begin{array}{l}0.9719^{\cdots \cdots} \\
(0.1294)\end{array}$ & $\begin{array}{l}2.3148 \\
(0.2165)\end{array}$ \\
\hline Firm-Specific Fixed Effect & $\begin{array}{c}0.2252 \cdots \cdots \\
(0.0330)\end{array}$ & $\begin{array}{c}0.2776 \\
(0.0446)\end{array}$ & $\begin{array}{c}0.8409^{\cdots *} \\
(0.1116)\end{array}$ & $(0.2626 \cdots$ & $\begin{array}{r}0.1019 \\
(0.0664)\end{array}$ & $\begin{array}{c}0.9212 \cdots \\
(0.1652)\end{array}$ & $\begin{array}{c}0.1678 \cdots \\
(0.0030)\end{array}$ & $\begin{array}{c}0.1616 \\
(0.0034)\end{array}$ & $\begin{array}{c}0.1364 \\
(0.0054)\end{array}$ \\
\hline Firm-Specific Seniority Returns & $\begin{array}{r}0.1753 \\
(0.1073)\end{array}$ & $\begin{array}{l}0.3932 \cdots \\
(0.1366)\end{array}$ & $\begin{array}{c}0.6705 * * \\
(0.2075)\end{array}$ & $\begin{array}{l}-1.99677^{\cdots * *} \\
(0.2799)\end{array}$ & $\begin{array}{l}-2.2268 \cdots \\
(0.3805)\end{array}$ & $\begin{array}{r}0.9989 \\
(0.9479)\end{array}$ & $\begin{array}{l}0.4158^{\cdots \cdots} \\
(0.0222)\end{array}$ & $\begin{array}{l}0.3919^{\cdots \cdots} \\
(0.0262)\end{array}$ & $\begin{array}{c}0.0764 \\
(0.0426)\end{array}$ \\
\hline Residual from Earnings Decomposition & $\begin{array}{r}0.0343 \\
(0.0226)\end{array}$ & $\begin{array}{l}0.1156^{\cdots \cdots} \\
(0.0325)\end{array}$ & $\begin{array}{r}0.0580 \\
(0.0848)\end{array}$ & $\begin{array}{r}0.0198 \\
(0.0250)\end{array}$ & $\begin{array}{c}0.0636^{\circ} \\
(0.0349)\end{array}$ & $\begin{array}{r}0.0358 \\
(0.0856)\end{array}$ & $\begin{array}{l}0.0902 \\
(0.0019)\end{array}$ & $\begin{array}{l}0.0894 \\
(0.0022)\end{array}$ & $(0.0790 \cdots$ \\
\hline \multicolumn{10}{|l|}{ Firm Accounts } \\
\hline Log(Total Employment) & $\begin{array}{r}0.0094 \\
(0.0064)\end{array}$ & $\begin{array}{l}0.0258^{\cdots \cdots} \\
(0.0081)\end{array}$ & $\begin{array}{l}0.0909^{* * * *} \\
(0.0177)\end{array}$ & $\begin{array}{l}0.05422^{* * * *} \\
(0.0065)\end{array}$ & $\begin{array}{l}0.0508 \cdots+\cdots \\
(0.0075)\end{array}$ & $\begin{array}{r}0.0088 \\
(0.0209)\end{array}$ & $\begin{array}{l}0.0206 \cdots \\
(0.0006)\end{array}$ & $\begin{array}{l}0.0254 \cdots \\
(0.0007)\end{array}$ & $\begin{array}{c}0.0343^{\cdots \cdots+} \\
(0.0013)\end{array}$ \\
\hline $\begin{array}{l}\log \text { (Value of Fixed Assets Net of } \\
\text { Depreciation and Amortization) }\end{array}$ & $\begin{array}{l}-0.1070 \cdots \\
(0.0112)\end{array}$ & $\begin{array}{l}-0.2732^{\cdots \cdots} \\
(0.0140)\end{array}$ & $\begin{array}{l}-0.30488^{* \cdots *} \\
(0.0300)\end{array}$ & $\begin{array}{l}-0.2583 \\
(0.0100)\end{array}$ & $\begin{array}{l}-0.0971 \cdots \\
(0.0126)\end{array}$ & $\begin{array}{l}-0.2618 \cdots \\
(0.0340)\end{array}$ & $\begin{array}{l}-0.0144 \cdots \\
(0.0007)\end{array}$ & $\begin{array}{l}-0.0143 \cdots \\
(0.0007)\end{array}$ & $\begin{array}{l}-0.0219 \cdots \\
(0.0013)\end{array}$ \\
\hline $\begin{array}{l}\text { Percent Increase in the Value of Fixed Assets } \\
\text { Net of Depreciation and Amortization }\end{array}$ & $\begin{array}{l}-5.400 \mathrm{E}-04 * * \\
(2.450 \mathrm{E}-04)\end{array}$ & $\begin{array}{l}1.730 \mathrm{E}-03 \\
(2.570 \mathrm{E}-04)\end{array}$ & $\begin{array}{l}-0.0022 \\
(0.0004)\end{array}$ & \begin{tabular}{|l}
$-8.100 \mathrm{E}-04 " *$ \\
$(3.560 \mathrm{E}-04)$
\end{tabular} & $\begin{array}{r}4.200 \mathrm{E}-05 \\
(1.180 \mathrm{E}-04)\end{array}$ & $\begin{array}{c}-0.0265 \\
(0.0094)\end{array}$ & $\begin{array}{l}1.190 \mathrm{E}-06 * * \\
(2.336 \mathrm{E}-07)\end{array}$ & $\begin{array}{l}1.116 \mathrm{E}-06 \\
(2.160 \mathrm{E}-07)\end{array}$ & $\begin{array}{l}2.087 \mathrm{E}-06 \\
(2.776 \mathrm{E}-07)\end{array}$ \\
\hline Log(Total Debt/Total Assets) & $\begin{array}{l}0.2613^{n+*} \\
(0.0408)\end{array}$ & $\begin{array}{l}0.2736 \\
(0.0496)\end{array}$ & $\begin{array}{r}0.0217 \\
(0.1097)\end{array}$ & $\begin{array}{l}0.2196 \\
(0.0444)\end{array}$ & $\begin{array}{l}0.3438^{\cdots \cdots} \\
(0.0503)\end{array}$ & $\begin{array}{l}-0.7780 \cdots+\cdots \\
(0.1399)\end{array}$ & $\begin{array}{c}0.0456 * * \\
(0.0037)\end{array}$ & $\begin{array}{l}0.0514 \\
(0.0040)\end{array}$ & $\begin{array}{l}0.0531 \\
(0.0059)\end{array}$ \\
\hline Log(Return on Assets) & $\begin{array}{l}0.0313^{\prime \cdots *} \\
(0.0115)\end{array}$ & $\begin{array}{c}0.0952^{\cdots \cdots} \\
(0.0143)\end{array}$ & $\begin{array}{c}0.0780 \\
(0.0309)\end{array}$ & $\begin{array}{c}0.0630 \\
(0.0101)\end{array}$ & $\begin{array}{l}-0.0737 \cdots \\
(0.0115)\end{array}$ & $\begin{array}{r}0.0528 \\
(0.0373)\end{array}$ & $\begin{array}{c}0.0330 \text { "** } \\
(0.0011)\end{array}$ & $\begin{array}{c}0.03288^{\cdots \cdots} \\
(0.0012)\end{array}$ & $\begin{array}{c}0.0403 \\
(0.0018)\end{array}$ \\
\hline Log(Value Added per Worker) & $\begin{array}{c}0.3777 \\
(0.0488)\end{array}$ & $\begin{array}{l}-0.12277^{\circ "} \\
(0.0599)\end{array}$ & $\begin{array}{l}-0.9281 \\
(0.1495)\end{array}$ & $\begin{array}{c}0.3617^{* * * *} \\
(0.0536)\end{array}$ & $\begin{array}{l}0.5152 \\
(0.0673)\end{array}$ & $\begin{array}{r}-0.1804 \\
(0.1992)\end{array}$ & $\begin{array}{l}-0.0900 \\
(0.0044)\end{array}$ & $\begin{array}{l}-0.0393 \\
(0.0049)\end{array}$ & $\begin{array}{c}0.0286 \\
(0.0076)\end{array}$ \\
\hline Log Likelihood & -5851.0055 & -3919.493 & -893.785 & -6703.903 & -4397.9905 & -914.871 & -562967.45 & -469649.625 & -198867.42 \\
\hline Pseudo-R Square (Rescaled) & 0.3553 & 0.3889 & 0.4779 & 0.5752 & 0.6225 & 0.7416 & 0.3157 & 0.3282 & 0.324 \\
\hline
\end{tabular}


Appendix Table 1

Types of Asset Transfers Covered by the MDST Data

\begin{tabular}{|c|c|c|c|c|c|}
\hline \multicolumn{6}{|c|}{ Perspective of the Characterization } \\
\hline \multicolumn{2}{|r|}{ Overall } & \multicolumn{2}{|r|}{ Transferring Enterprise } & \multicolumn{2}{|r|}{ Receiving Enterprise } \\
\hline Code & Definition & Code & Definition & Code & Definition \\
\hline 01 & Change of Operator or Legal Structure & 12 & Change of Operator or Legal Structure & 11 & Change of Operator or Legal Structure \\
\hline 09 & Change of Identifier for Unknown Reason & 19 & $\begin{array}{l}\text { Quasi-Constant Structure (Without Change of } \\
\text { Owner or Legal Structure) }\end{array}$ & 19 & $\begin{array}{l}\text { Quasi-Constant Structure (Without Change of } \\
\text { Owner or Legal Structure) }\end{array}$ \\
\hline 20 & Partial Investments Between Enterprises & 22 & Investment in Another Enterprise & 21 & Received Investment by Another Enterprise \\
\hline 30 & Acquisition of One or Several Enterprises & 23 & Acquisition by Another Enterprise & 24 & $\begin{array}{c}\text { Acquired Another Enterprise } \\
\text { Complicated Change of Structure, Enterprise }\end{array}$ \\
\hline 40 & Partial Divestiture of One or Several Enterprises & 25 & $\begin{array}{c}\text { Partiel Divestiture } \\
\text { Transformation into Holding Company after }\end{array}$ & 29 & Still Exists \\
\hline 50 & Total Divestiture (Breaking Up) of an Enterprise & 27 & $\begin{array}{c}\text { Partial Divestiture } \\
\text { Transformation into Leasing Company after }\end{array}$ & 41 & Creation Due to a Partial Divestiture \\
\hline 60 & Merger of One or Several Enterprises & 28 & $\begin{array}{c}\text { Partial Divestiture } \\
\text { Complicated Change of Structure, Enterprise }\end{array}$ & 42 & Creation Due to a Total Divestiture \\
\hline 70 & Transformation into Holding Company & 29 & Still Exists & 43 & $\begin{array}{c}\text { Creation by Merger of Several Enterprises } \\
\text { Created in N-1 and Participating in a }\end{array}$ \\
\hline 80 & Transformation into Leasing Company & 31 & Acquisition by Another Enterprise & 49 & Complicated Change of Structure \\
\hline 90 & Complicated Change of Structure & $\begin{array}{l}32 \\
33 \\
39\end{array}$ & $\begin{array}{c}\text { Ceased to Exist in N-1 Due to Divestiture } \\
\text { Ceased to Exist in N-1 Due to Merger } \\
\text { Acquisition in N-1 }\end{array}$ & & \\
\hline
\end{tabular}



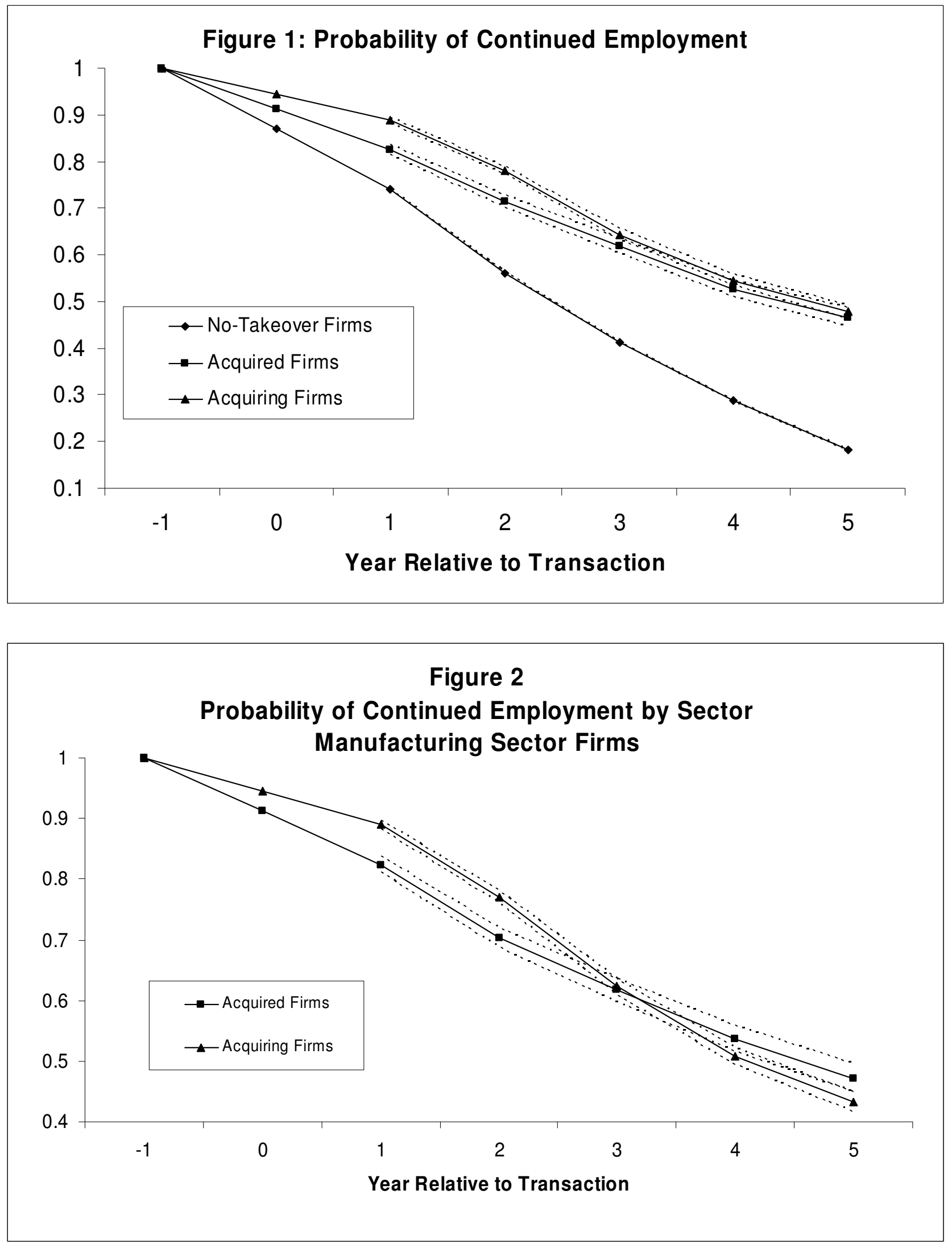

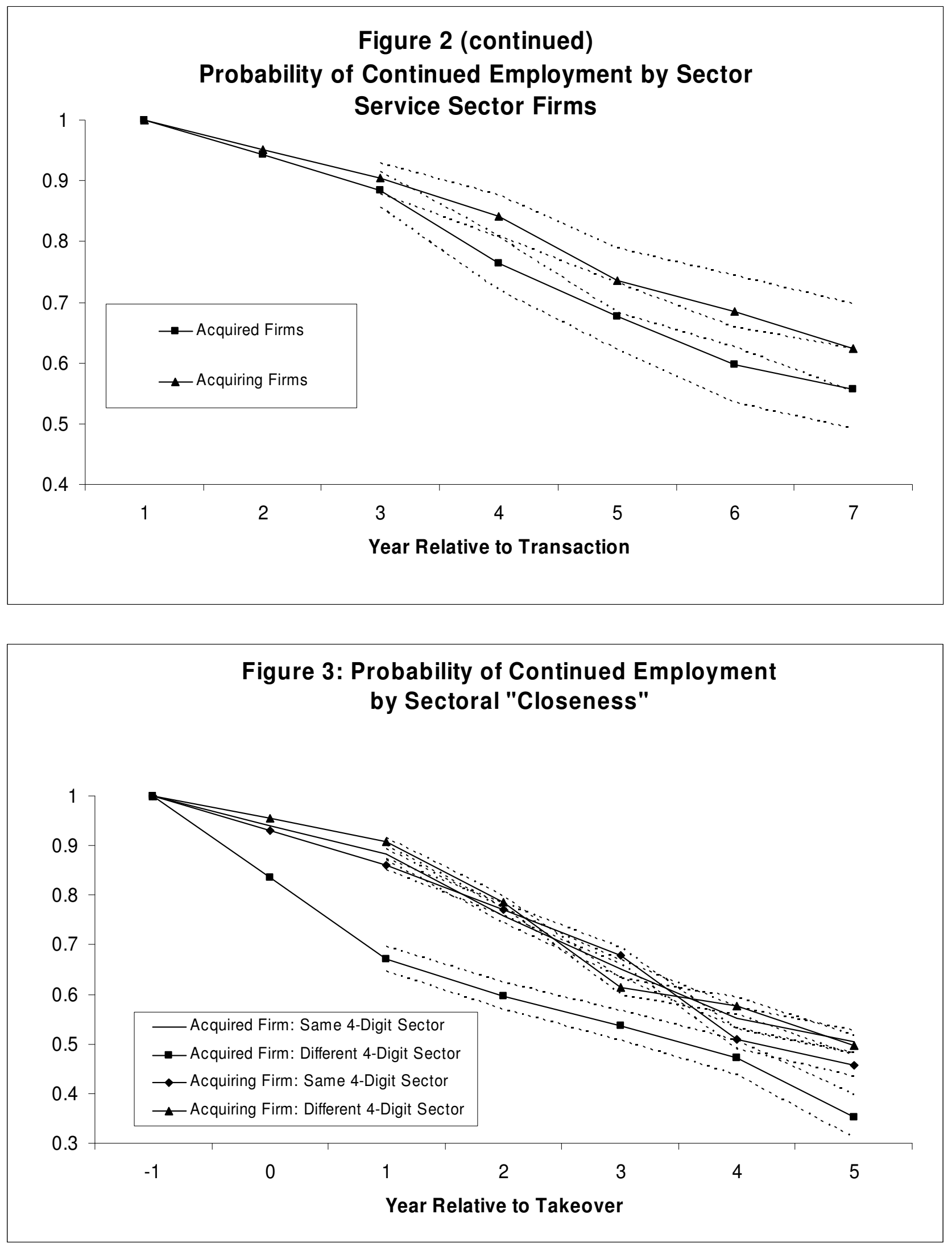